Review

\title{
Fluorescent Proteins for Investigating Biological Events in Acidic Environments
}

\author{
Hajime Shinoda ${ }^{1}$, Michael Shannon ${ }^{2}$ and Takeharu Nagai ${ }^{1,2, *}$ \\ 1 Department of Biotechnology, Graduate School of Engineering, Osaka University, 2-1 Yamadaoka, \\ Suita 565-0871, Japan; 4nd40@sanken.osaka-u.ac.jp \\ 2 The Institute of Scientific and Industrial Research, Osaka University, 8-1 Mihogaoka, Ibaraki 567-0047, Japan; \\ mi9@sanken.osaka-u.ac.jp \\ * Correspondence: ng1@sanken.osaka-u.ac.jp; Tel.: +81-(0)6-6879-8481
}

Received: 2 May 2018; Accepted: 19 May 2018; Published: 23 May 2018

\begin{abstract}
The interior lumen of acidic organelles (e.g., endosomes, secretory granules, lysosomes and plant vacuoles) is an important platform for modification, transport and degradation of biomolecules as well as signal transduction, which remains challenging to investigate using conventional fluorescent proteins (FPs). Due to the highly acidic luminal environment ( $\mathrm{pH} \sim 4.5-6.0)$, most FPs and related sensors are apt to lose their fluorescence. To address the need to image in acidic environments, several research groups have developed acid-tolerant FPs in a wide color range. Furthermore, the engineering of $\mathrm{pH}$ insensitive sensors, and their concomitant use with $\mathrm{pH}$ sensitive sensors for the purpose of $\mathrm{pH}$-calibration has enabled characterization of the role of luminal ions. In this short review, we summarize the recent development of acid-tolerant FPs and related functional sensors and discuss the future prospects for this field.
\end{abstract}

Keywords: fluorescent protein; GFP; acidic organelle; lysosome; secretory granule; endosome; pH; pH-sensitivity; $\mathrm{Ca}^{2+}$; FRET

\section{Introduction}

For cells to maintain their function, the construction and transportation of useful biomolecules must be balanced with the degradation and recycling of unnecessary ones. Acidic organelles (e.g., endosomes, secretory granules, lysosomes, plant vacuoles, etc.) play an important role in biomolecule degradation. Such organelles maintain luminal $\mathrm{pH}(\mathrm{pH} \sim 4.5-6.0)$, and contain many unique modification and degradation enzymes that actively work in acidic conditions [1]. In addition to these well characterized functions, their involvement in the cell-wide signaling network has recently been elucidated $[2,3]$. In particular, $\mathrm{Ca}^{2+}$ release from and uptake into acidic organelles (in concert with other $\mathrm{Ca}^{2+}$-storing organelles, mainly the endoplasmic reticulum) has been shown to control local $\mathrm{Ca}^{2+}$ levels in the cytosol, leading to the regulation of biological events such as autophagy, apoptosis and membrane repair [4]. Intraluminal $\mathrm{Cl}^{-}$acts as a major counterion during the V-ATPase dependent acidification of endocytic and secretory organelles. It has also been reported that the disturbance of $\mathrm{Cl}^{-}$transport into/out of vesicles leads to impaired membrane-trafficking [5]. Additionally, levels of amino acids in lysosomes control activity of the mTOR complex 1 (mTORC1) on the lysosomal membrane, regulating the autophagic pathway to control biosynthesis and the catabolic state [6].

Fluorescent proteins (FPs) are some of the most useful tools to investigate these cellular functions [7]. They enable us to observe the spatial dynamics of biomolecules and have been adapted to sense ions (for example $\mathrm{Ca}^{2+}, \mathrm{Mg}^{2+}, \mathrm{Zn}^{2+}, \mathrm{K}^{+}, \mathrm{Cl}^{-}$) in living cells, all of which are highly important for signal transduction. FPs and FP-based sensors can easily be localized to acidic organelles by fusing them to signal peptides or organelle-specific proteins. However, the application of FPs to 
study the lumen of acidic organelles has been limited because: (1) many FPs that are practical for neutral $\mathrm{pH}$ imaging tend to lose fluorescence in acidic conditions due to their neutral $\mathrm{p} K_{\mathrm{a}}$ of 6.0 [8]; and (2) functional domains used in most FP-based sensors change their affinity to target molecules depending on $\mathrm{pH}$, complicating data analysis in acidic organelles in which $\mathrm{pH}$ is variable and sometimes dynamic. To overcome these limitations, acid-tolerant FPs have been developed, and FP-based sensors have been used in combination with $\mathrm{pH}$ sensors to compensate for effects triggered by $\mathrm{pH}$ change. In this short review we introduce the recent development of acid-tolerant FPs and compare mechanisms of $\mathrm{pH}$ sensitivity in conventional FPs with acid-tolerant ones. We show examples of the application of FP-based sensors in acidic organelles and discuss the future prospects for this field.

\section{GFP-Like Protein}

\subsection{Green-Yellow-Red Fluorescent Protein}

Green and yellow FPs are widely used by researchers because of their brightness, fast and simple chromophore maturation mechanism, and excellent photostability. GFPs form a $p$-hydroxybenzylideneimidazolinone chromophore, containing a hydroxyphenyl ring originating from a side chain of Tyr. YFP is a slightly red-shifted variant of GFP, a shift that is caused by a $\pi-\pi$ stacking interaction between the chromophore and a neighboring hydroxyphenyl ring from a Tyr side chain [7]. At neutral $\mathrm{pH}$, a phenolate oxide of the GFP or YFP chromophore is deprotonated by hydrogen bonding with a neighboring amino acid (usually an $\mathrm{OH}$ group of a side chain of Ser or Thr) and a water molecule. In this situation an electron can be reversibly relayed between the phenolate oxide ion and imidazole ring to form an imidazole oxide ion. This results in the extension of a $\pi$ conjugation system and resultant light energy absorption with a peak at around $480-500 \mathrm{~nm}$. Additionally, the hydrogen bonds at the phenolate oxide stabilize the chromophore by limiting the movement caused by thermal fluctuation, enabling effective energy conversion of the chromophore as it relaxes from the excited state and emits fluorescence. On the other hand, in acidic $\mathrm{pH}$ the phenolate oxide is protonated, which causes contraction of the $\pi$ conjugation system and a shift in absorption to the UV spectral region (a peak at around 360-380 nm) (Figure 1A). Absence of a hydrogen bond at the phenolate oxide increases thermal fluctuation of the chromophore, so that excited state energy in the chromophore is likely to be consumed by thermal relaxation, leading to a decrease in the fluorescence quantum yield. Because of this acid-quenching mechanism, most widely-used GFPs and YFPs are $\mathrm{pH}$ sensitive ( $\mathrm{p} K_{\mathrm{a}}$ for EGFP: 6.0, mEmerald: 6.0, sfGFP: 5.5, mNeonGreen: 5.7, mClover: 5.9, mCitrine: 5.7, mVenus: 6.0 [8], Table 1).

Several wild-type GFPs less sensitive to $\mathrm{pH}$ such as CpYGFP $\left(\mathrm{p} K_{\mathrm{a}}=4.4\right)$ [9], bfloGFPa1 $\left(\mathrm{p} K_{\mathrm{a}}=4.0\right)$ [10] and $\mathrm{zFP506}\left(\mathrm{p} K_{\mathrm{a}}<4.0\right)$ [11] were originally reported, however their application to imaging has been limited. This is because they form homo-dimeric or -tetrameric structures under physiological conditions and/or form aggregates in cells, which can cause dysfunction or mislocalization of the fused proteins. Recently, a monomeric and bright acid-tolerant GFP: Gamillus, has been developed from flower hat jellyfish (Olindias formosa) [12]. Gamillus emits fluorescence with the same brightness and photo-physics over a wide $\mathrm{pH}$ range of 4.5 to 9.0, covering almost all physiological $\mathrm{pH}$ values observed inside cells $\left(\mathrm{p} K_{\mathrm{a}}=3.4\right)$. Mechanistically, it has been suggested that the unique trans configuration of the chromophore phenyl ring is important for acid-tolerance. Gamillus exhibits a photochromic decrease in fluorescence to $60 \%$ or $10 \%$ of its initial intensity when excited by $457-487 \mathrm{~nm}$ or $488-512 \mathrm{~nm}$, which is rapidly recovered by subsequent excitation with 352-388 nm light. On the other hand, it shows a negligible photochromic decrease when excited by 440-480 nm light. Therefore, with care and caution to avoid undesired photochromic effects, Gamillus will help researchers to perform multicolor imaging or FRET analysis to investigate biological events inside acidic cellular environments.

Red FPs derived from GFP-like proteins form chromophores containing the same hydroxyphenyl ring as in GFP but with further extension of the $\pi-\pi$ conjugation system to form an acylimine structure (Figure 1B). Therefore, as $\mathrm{pH}$ decreases, red FPs tend to decrease fluorescence by the same mechanism 
as GFP and YFP. Compared with GFP and YFP based proteins however, many more monomeric acid-tolerant RFPs have been reported (to the best of our knowledge, as to why RFP tends to have higher acid-tolerance than GFP has not been well studied). Among the reported RFPs, DsRed-derivatives such as mRFP1 (pK $\left.K_{\mathrm{a}} \leq 4.5\right)$ [13], mCherry (<4.5) [14], mCherry2 (3.3) [15], mStrawberry (<4.5) [14], mScarlet (5.3) [16], mPlum (<4.5) [17] and mRaspberry (<4.5) [17], eqFP611-derivatives such as mRuby (4.4) [18], mRuby2 (5.3) [19] and mRuby3 (4.8) [20], and eqFP578-derivatives such as tagRFP (3.1) [21], TagRFP657 (3.4) [22], FusionRed (4.6) [23] are widely-used and highly pH-stable. DsRed- and eqFP611-derived FPs are likely resistant to proteolytic degradation in lysosomes, whereas eqFP578-derived FPs are not (the detail will be discussed in the following section). Therefore, in order to observe lysosome-related events, careful choice of FPs is necessary. For the application to acidic-organelles aside from lysosomes, FusionRed may be well-suited because of its superior monomeric property and less toxicity in comparison with other RFPs including mCherry and mRuby [23].

Large-Stokes-shift FPs (LSS-FP) such as mT-Sapphire (green) [24] and LSSmKate (red) [25] adopt a neutral Tyr side chain in their chromophore at steady state. When the neutral chromophore is excited, it converts to the excited intermediate anion form via proton transfer to a neighboring side chain of Asp/Glu (an example of so-called excited-state proton transfer (ESPT)) (Figure 1C). Red-shifted fluorescence is then emitted when excited electron $\left(S^{1}\right)$ transit to the ground state $\left(S^{0}\right)$. In the case of LSSmKate, pH sensitivity depends on the ionic state of Asp/Glu160 which act as a proton acceptor for the chromophore hydroxyphenol moiety via ESPT [26]. At $\mathrm{pH}$ levels below 3.5, the carboxylate group of Glu / Asp160 is protonated so that ESPT does not occur. Probably because $\mathrm{p} K_{\mathrm{a}}$ of Glu/Asp side chains is low, LSSmKate1 and LSSmKate2 exhibit high acid-tolerance with $\mathrm{p} K_{\mathrm{a}}$ of 3.2 and 2.7, respectively.
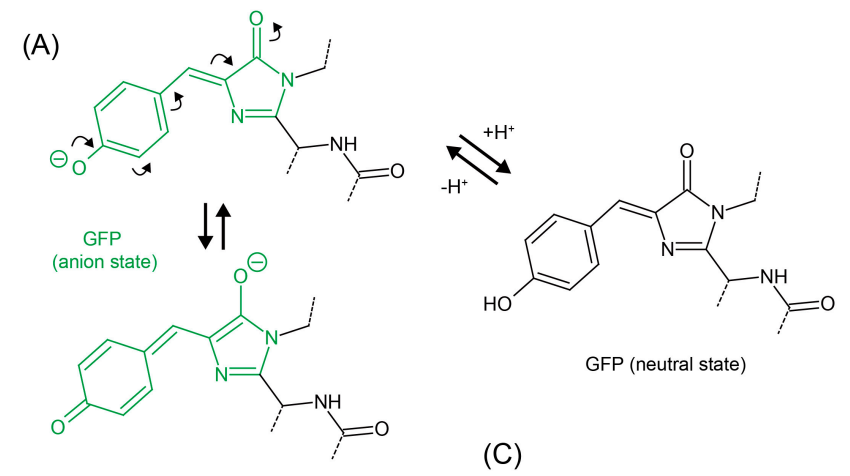

(B)

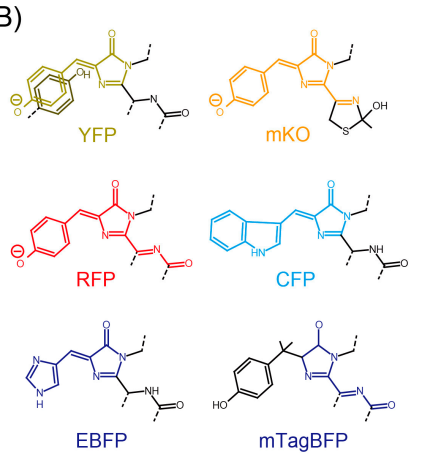

(C)

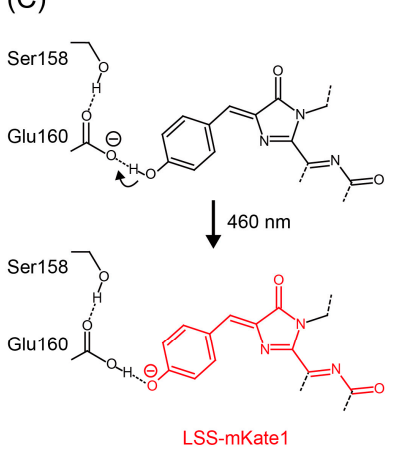

Figure 1. Chromophore structures of GFP-like proteins. (A) Protonation of the GFP chromophore causes contraction of the $\pi$ conjugation system, resulting in an absorption spectral shift from $480-500 \mathrm{~nm}$ to $360-380 \mathrm{~nm}$. The protonation also makes the chromophore unstable and results in a fluorescence quantum yield decrease; (B) Chemical structures of selected GFP-like proteins. The $\pi$-conjugation system responsible for fluorescence emission are colored to correspond with the color of fluorescence emission; (C) Excited state proton transfer (ESPT) in LSS-mKate1. Glu160 act as a proton acceptor in ESPT. 
Table 1. Optical property of acid-tolerant GFP-like proteins.

\begin{tabular}{|c|c|c|c|c|c|c|c|c|c|}
\hline Color & Protein & $\lambda_{\text {ex/em }}{ }^{a}(n m)$ & $\begin{array}{c}\varepsilon^{\mathrm{b}}\left(\mathbf{( 1 0}^{3} \mathrm{M}^{-1}\right. \\
\left.\mathrm{cm}^{-1}\right)\end{array}$ & $Q^{c}$ & Bright-ness $^{d}$ & $\begin{array}{l}\text { Oligomeric State e } \\
\text { (In Vitro/OSER) }\end{array}$ & $\mathrm{p} K_{\mathrm{a}}{ }^{\mathrm{f}}$ & $\begin{array}{l}\text { Resistance to Lysosomal } \\
\text { Enzymes }\end{array}$ & Ref. \\
\hline \multirow{2}{*}{ Blue } & Sirius & $355 / 424$ & 15.0 & 0.24 & 3.6 & mono/N.D. & $<3.0$ & Yes $\mathrm{g}$ & [27] \\
\hline & mTagBFP2 & $399 / 454$ & $50.6(76.0)$ & $0.64(0.48)$ & $32.4(36.5)$ & mono/oligo & $2.7(2.4)$ & eqFP578-derivatives. Maybe no. & [28] \\
\hline \multirow{3}{*}{ Cyan } & mTurquoise2 & $434 / 474$ & $30.0(31.0)$ & $0.93(0.92)$ & $27.9(28.5)$ & mono/mono & $3.1(3.6)$ & \multirow{3}{*}{$\begin{array}{l}\text { avGFP-derivatives. Maybe no. } \\
{[29]^{\mathrm{h}}} \\
\text { N.D. }\end{array}$} & [30] \\
\hline & mCerulean3 & $434 / 475$ & $40.0(29.0)$ & $0.80(0.80)$ & $32.0(23.2)$ & mono/mono & $3.2(3.4)$ & & [31] \\
\hline & mTFP1 & $462 / 492$ & $64.0(53.0)$ & $0.85(0.85)$ & $54.4(45.1)$ & mono/mono & $4.3(4.3)$ & & [32] \\
\hline UV-excitable Green & mT-Sapphire & $399 / 511$ & $44.0(34.0)$ & $0.60(0.59)$ & $26.4(20.1)$ & mono/mono & $4.9(4.8)$ & \multirow{4}{*}{ avGFP-derivatives. Basically no. } & [24] \\
\hline \multirow{3}{*}{ Green } & ECGFP & $463 / 506$ & 23.9 & 0.14 & 3.3 & mono/N.D. & $<4.0$ & & [33] \\
\hline & mEmerald & $487 / 509$ & $57.5(62.0)$ & $0.68(0.75)$ & $39.1(46.5)$ & mono/mono & $6.0(4.6)$ & & [34] \\
\hline & pH-tdGFP & $488 / 515$ & N.D. & N.D. & N.D. & tandem-dimer & 4.8 & & [35] \\
\hline \multirow{3}{*}{ Yellow-Green } & mVenus & $515 / 527$ & $105.0(127.0)$ & $0.64(0.67)$ & $67.2(85.1)$ & mono/mono & $6.0(5.4)$ & \multirow{3}{*}{$\begin{array}{c}\text { Yes } \\
\text { Maybe no [12] }\end{array}$} & [36] \\
\hline & Gamillus & $504 / 519$ & 83.0 & 0.90 & 74.7 & mono/mono & 3.4 & & [12] \\
\hline & mNeonGreen & $506 / 517$ & $116.0(113.0)$ & $0.80(0.80)$ & $92.8(90.4)$ & mono/mono & $5.7(5.4)$ & & [37] \\
\hline Orange & mKOk & $551 / 563$ & 105.0 & 0.61 & 64.1 & mono/N.D. & 4.2 & N.D. & [38] \\
\hline \multirow{11}{*}{ Red } & mRFP1 & $584 / 607$ & $50.0(55.0)$ & $0.25(0.35)$ & $12.5(19.3)$ & mono/mono & $4.5(3.8)$ & \multirow{5}{*}{$\begin{array}{l}\text { DsRed-derivatives. Basically yes. } \\
\text { [39] }\end{array}$} & [13] \\
\hline & mCherry & $587 / 610$ & $72.0(85.0)$ & $0.22(0.30)$ & $15.8(25.5)$ & mono/mono & $<4.5(3.8)$ & & [14] \\
\hline & mCherry2 & $589 / 610$ & 79.4 & 0.22 & 17.5 & mono/N.D. & 3.3 & & [15] \\
\hline & mStrawberry & $574 / 596$ & 90.0 & 0.29 & 26.1 & mono/mono & $<4.5$ & & [14] \\
\hline & mScarlet & $569 / 594$ & 100.0 & 0.70 & 70.0 & mono/mono & 5.3 & & [16] \\
\hline & mRuby & $558 / 605$ & $112.0(109.0)$ & $0.35(0.38)$ & $39.2(41.4)$ & mono/mono & $4.4(4.4)$ & \multirow{3}{*}{$\begin{array}{l}\text { eqFP611-derivatives. Basically } \\
\text { yes. [39] }\end{array}$} & [18] \\
\hline & mRuby2 & $559 / 600$ & $113.0(107.0)$ & $0.38(0.37)$ & 42.9 (39.6) & mono/mono & $5.3(4.4)$ & & [19] \\
\hline & mRuby3 & $558 / 592$ & 128.0 & 0.45 & 57.6 & mono/N.D. & 4.8 & & [20] \\
\hline & TagRFP & $555 / 584$ & $100.0(130.0)$ & $0.48(0.33)$ & $48.0(42.9)$ & mono/oligo & $3.1(3.0)$ & \multirow{5}{*}{$\begin{array}{l}\text { eqFP578-derivatives. Basically } \\
\text { no. [39] }\end{array}$} & [21] \\
\hline & TagRFP-T & $555 / 584$ & $81.0(106.0)$ & $0.41(0.32)$ & $33.2(33.9)$ & mono/oligo & $4.6(4.3)$ & & [40] \\
\hline & FusionRed & $580 / 608$ & $83.0(85.0)$ & $0.19(0.30)$ & $15.8(25.5)$ & mono/mono & $4.6(4.2)$ & & [23] \\
\hline \multirow{3}{*}{ Blue-excitable Red } & LSSmKate1 & $463 / 624$ & 31.2 & 0.08 & 2.5 & mono/N.D. & 3.2 & & [25] \\
\hline & LSSmKate2 & $460 / 605$ & 26.0 & 0.17 & 4.4 & mono/N.D. & 2.7 & & [25] \\
\hline & hmKeima4.15 & $436 / 612$ & 28.0 & 0.29 & 8.1 & mono/N.D. & 5.2 & mKeima-derivative. Maybe yes. & [41] \\
\hline \multirow{3}{*}{ Far Red } & mPlum & $590 / 649$ & $41.0(80.0)$ & $0.10(0.13)$ & $4.1(10.4)$ & mono/mono & $<4.5(4.6)$ & \multirow{3}{*}{$\begin{array}{l}\text { DsRed-derivatives. Maybe yes. } \\
\text { eqFP578-derivatives. Maybe no. }\end{array}$} & [17] \\
\hline & mRaspberry & $598 / 625$ & 86.0 & 0.15 & 12.9 & mono/mono & $<4.5$ & & [17] \\
\hline & TagRFP657 & $611 / 657$ & 34.0 & 0.10 & 3.4 & mono/N.D. & 3.4 & & [22] \\
\hline
\end{tabular}

${ }^{\mathrm{a}}$ Wavelength of excitation and emission peaks; ${ }^{\mathrm{b}}$ Molar extinction coefficient; ${ }^{\mathrm{c}}$ Fluorescence quantum yield; ${ }^{\mathrm{d}}$ Product of $\varepsilon$ and QY, divided by $1000 ;{ }^{\mathrm{e}}$ Oligomeric state of FPs determined by gel-filtration chromatography (in vitro) or OSER assay with mammalian cells; ${ }^{\mathrm{f}} \mathrm{pH}$ at which fluorescence intensity becomes its half-maximal value; ${ }^{\mathrm{g}}$ Sirius is derived from avGFP, however it kept emitting fluorescence in phagosomes in Dictyostelium discoidium; ${ }^{\text {h }}$ FPs from the same origin tend to show similar resistance to proteolytic degradation in lysosomes. Values without parentheses are from original articles. Values indicated in parentheses are referred from a paper [8]. N.D. indicates "Not Determined". 


\subsection{Blue-Cyan Fluorescent Protein}

Color variants that emit shorter wavelengths of light such as ECFP (cyan), EBFP (blue) and Sirius (ultramarine) were artificially constructed from A. victoria-derived GFP by substitution of the Tyr residue constituting the chromophore with a Trp, His or Phe residue, respectively [7]. The side chains of Trp, His and Phe in these chromophores are neutral or cationic state, in the $\beta$-barrel, at steady state, and environmental $\mathrm{pH}$ decrease causes a slight shrinkage of the $\pi-\pi$ conjugation system as in the case of the GFP chromophore. Their fluorescence loss by $\mathrm{pH}$ decrease is mostly accompanied not with an absorption spectral shift but with a decrease in the fluorescence quantum yield. In this color range, several acid-tolerant FPs have been reported as follows. Sirius, a FP with Phe-derived chromophore emitting the shortest wavelength of excitation/emission peaks (355/424 nm), shows the highest acid-tolerance of all FPs, where its fluorescence intensity is essentially constant between $\mathrm{pH}$ 9.0 and $3.0\left(\mathrm{p} K_{\mathrm{a}}<3.0\right.$, Table 1) [27]. However, the molecular brightness is low $\left(\varepsilon: 15,000 \mathrm{M}^{-1} \cdot \mathrm{cm}^{-1}\right.$; QY: 0.24 ), and UV illumination to excite Sirius is likely to cause cytotoxicity. The best options so far are mTurquoise2 [30] and mCerulean3 [31], improved versions of ECFP with $\mathrm{pH}$-insensitive indole rings. Their low $\mathrm{p} K_{\mathrm{a}}$ values (3.1 and 3.2, respectively) and high molecular brightness $\left(\varepsilon: 30,000 \mathrm{M}^{-1} \cdot \mathrm{cm}^{-1}\right.$; QY: 0.93 for mTurquoise2; $\varepsilon: 40,000 \mathrm{M}^{-1} \cdot \mathrm{cm}^{-1}$, QY: 0.80 for mCerulean3) make them amenable for use in acidic environments. Because of their high quantum yields, these FPs can serve as effective FRET donors for GFP and YFP. pH-tolerant Cyan-Green FP, ECGFP was also engineered from ECFP by substituting Thr underneath the chromophore with Tyr (T203Y) [33]. This substitution introduced $\pi-\pi$ interaction between the chromophore's indole ring and the Tyr's phenolate ring, resulting in the shift of excitation/emission peaks from $434 / 476 \mathrm{~nm}$ to $463 / 506 \mathrm{~nm}$. Another type of Blue FP, mTagBFP (and mTagBFP2) was developed by introducing mutations, which (1) prevent chromophore maturation from blue to red and (2) stabilize the blue protonated intermediate [28]. mTagBFP contains $N$-acylimine, the same chromophore as in TagRFP, but lacks a $C^{\alpha}-C^{\beta}$ double bond in the Tyr side chain. mTagBFP2 shows the highest molecular brightness $\left(\varepsilon: 50,600 \mathrm{M}^{-1} \cdot \mathrm{cm}^{-1}\right.$; QY: 0.64$)$ and acid tolerance $\left(\mathrm{p} K_{\mathrm{a}}=2.7\right)$ of all blue FPs.

\subsection{Character and Stability of $\beta$-Barrel Structure}

Chromophores from GFP-like proteins appear at first glance almost completely shielded by the rigid $\beta$-barrel structure. However, most GFP-like proteins have an unstructured loop region in the middle of the 7th $\beta$-strand, which makes a cleft-like structure between the 7th and 10th $\beta$-strand [42]. Some FPs such as Dronpa and TurboGFP have a water-filled opening there, and this connects the chromophore with bulk solvent. This opening may well be important for facilitating oxygen conveyance from the bulk solution to the premature chromophore, which may speed up the process of maturation [43]. Meanwhile, the opening possibly relays environmental $\mathrm{pH}$ changes to the chromophore, enhancing its $\mathrm{pH}$ sensitivity. Although the apparent opening has rarely been observed in the structure of other FPs, this opening at the same position may occur for other GFPs too. A molecular dynamics study has identified that fluctuation of the 6th-7th strand can generate an opening with enough size for water molecules passing through [44]. Also, X-ray crystallographic study of KillerRed revealed a water-filled channel at a different position reaching from an end cap of the $\beta$-barrel to the chromophore [45]. Therefore these are likely the reason why chromophores protected by rigid $\beta$-barrel structures are sensitive to $\mathrm{pH}$. Resistance of the $\beta$-barrel structure itself to acidic quenching is also an important point. For example, at $\mathrm{pH}$ below 5.0, fluorescence intensity of EGFP and DsRed gradually decreases, and does not fully recover to the initial intensity after readjusting the $\mathrm{pH}$ to neutral. CD spectral measurement of DsRed revealed that the secondary structure breaks down in $\mathrm{pH}$ 4.1 buffer [46]. 


\subsection{Resistance to Degradative Enzymes in Lysosomes}

It has been observed that several days after transfection, some types of non-fused GFP-like proteins exhibit fluorescent puncta in cells, the localization pattern of which resembles that of lysosomes [29]. FPs in the cytosol are likely to be delivered to lysosomes by autophagy-related activity, then those resistant to both acidic quenching and degradation enzymes keep emitting fluorescence there. Incubation of several jellyfish-derived FPs (EGFP, ECFP and Sapphire) in pH 5.0 buffer containing lysosomal contents resulted in their loss of detection (relevant bands) by SDS-PAGE, while the same experiment with coral-derived FPs (such as DsRed, mRFP1 and zFP506) showed detection by SDS-PAGE at the expected size-positions. The control experiment using $\mathrm{pH} 5.0$ buffer without lysosomal contents for both of the jellyfish- and coral-derived FPs also resulted in the appearance of the bands [29], together suggesting that only coral-derived FPs are resistant to acidic lysosomal degradation. For observation of events in the cytosol with FPs, this property is sometimes a problem because the fluorescent puncta may perturb analysis of imaging data and have a negative effect on long-term cell viability [39]. Meanwhile, FP resistance to degradation in lysosomes is essential for their application to lysosome-related imaging. For this purpose, mCherry and Gamillus are preferable because of their high resistance in lysosomes and their monomeric properties.

In addition, it has to be kept in mind that possible peptide cleavage may occur between the FP and the fused protein. It was reported that mCherry fused with the C-terminus of lysosomal proteins such as Niemann-Pick disease type C protein 2 (NPC2) and lysosomal protease tripeptidyl peptidase I (TPP1) showed separation of the two proteins due to lysosomal degradation enzymes [47]. This cleavage was suppressed by deletion of a flexible 11 amino acid region from the $\mathrm{N}$-terminus of mCherry and the use of a rigid linker composed of 5 or 10 prolines. Therefore, to study trafficking of protein-complexes in lysosomes, which then travel from lysosomes to other organelles or plasma membrane, such linker optimization to prevent FP-fusion protein cleavage has to be considered.

\section{FP-Based Sensor for Acidic Organelle Imaging}

\subsection{FP-Based Sensor and Chemical Dye-Based Sensor}

To investigate the role of ions inside acidic organelles (e.g., $\mathrm{Ca}^{2+}, \mathrm{Zn}^{2+}$ and $\mathrm{Cl}^{-}$) and acidic organelle-related cellular events (e.g., autophagy, exocytosis and endocytosis), several organic dye-based and FP-based sensors have been developed (Table 2). Comparing the two types of sensor, organic dye-based sensors have advantages that include higher brightness, less photobleaching, easy sample preparation and superior resistance to acidic environments and degradative enzymes. The last characteristic is especially important for imaging applications in lysosomes. Accordingly, many organic dye-based sensors have been developed to obtain information about lysosomal ion concentration. Some organic dyes however are cytotoxic, (e.g., widely-used $\mathrm{Ca}^{2+}$ sensors such as Fluo-4 acetoxymethyl (AM), Rhod-2 AM and Fura-2-AM can suppress activity of $\mathrm{Na}^{+}$- and $\mathrm{K}^{+}$-dependent adenosine triphosphatase (Na,K-ATPase) [48]) so careful interpretation of data obtained with these dyes is necessary. In contrast, FP-based sensors have the advantage that they can be expressed in specific cell-types using a cell-selective promoter and can be easily localized to cellular compartments of interest by fusing them with organelle-specific targeting motifs or proteins. FP-based sensors, therefore, have been preferred for in vivo imaging [49], and imaging in specific organelles such as secretory granules, endosomes and Golgi body which are difficult for chemical dye-based sensors to correctly target (see Table 2). Their application in lysosomes is currently very limited due to the generally high $\mathrm{pH}$ sensitivity of FP fluorescence and their weak resistance to acidic quenching and proteolytic degradation.

In the following section, we introduce several examples of the development and application of FP-based functional sensors in acidic organelles (Figure 2 and Table 2). Before moving to that topic, we explain how $\mathrm{pH}$-dependent properties of FP-based sensors can introduce difficulties when investigating acidic organelles. We emphasize the importance of simultaneous measurement of $\mathrm{pH}$ 
values during imaging for calibration of the sensor. To the best of our knowledge, all ionic sensors are somewhat sensitive to $\mathrm{pH}$ changes (organic dyes are no exception). Additionally, placing the inherent $\mathrm{pH}$ sensitivity of FPs aside for a moment, the ionic state of functional binding domains in FP-based sensors, which are positively or negatively charged to trap their specific counter ions (e.g., $\mathrm{Ca}^{2+}, \mathrm{Zn}^{2+}$, $\mathrm{Cl}^{-}$), can be affected by $\mathrm{pH}$ changes. Generally, $\mathrm{pH}$ decreases results in decreased affinity for cation sensors and increased affinity for anion sensors. In addition, environmental $\mathrm{pH}$ alters electric charge on the protein surface (London forces [50] as well as ionic forces), which can change the ionic interaction between two FPs (in the case of FRET-based sensors) or that between the FP and the functional domain. $\mathrm{pH}$ values in acidic organelles are very dynamic in many cases, as listed here: (1) the maturation process from early endosomes to late endosomes (a pH drop from 6.3 to 5.5 [51]; (2) the starvation induced-pH drop in lysosomes which results in increased activity of lysosomal degradation enzymes to facilitate turnover of biomolecules [52]; (3) the fusion of several membrane vesicles (e.g., during formation of autolysosome); and (4) the release or collection of ions though channels or pumps on the membranes of acidic organelles accompanied with $\mathrm{pH}$ changes in order to balance ion gradients or for use in proton-motive force [53,54]. Therefore, discreet investigation of the $\mathrm{pH}$-dependent property of sensors and careful $\mathrm{pH}$-calibration of imaging data is essential to validate imaging results. 
A)

mKeima (Dual-excitation ratiometric $\mathrm{pH}$ sensor for autophagy detection)
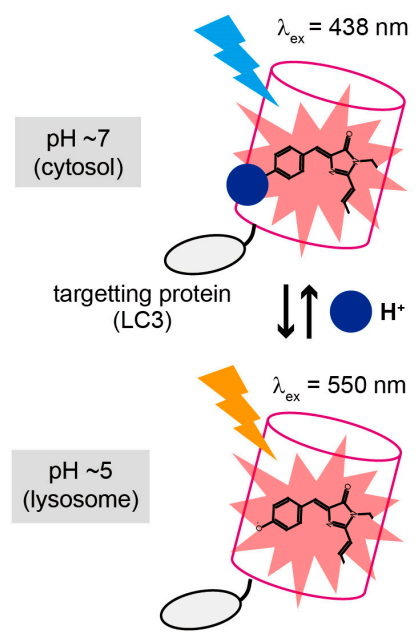

C)

eZinCh (FRET-based $\mathrm{Zn}^{2+}$ sensor)

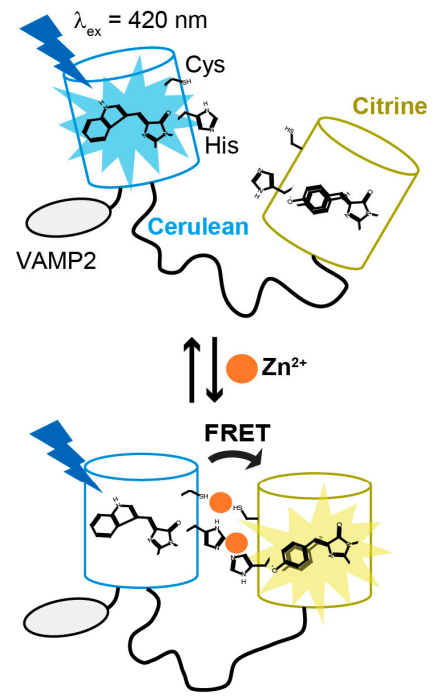

B)

D1-SG (FRET-based $\mathrm{Ca}^{2+}$ and $\mathrm{H}^{+}$sensor)
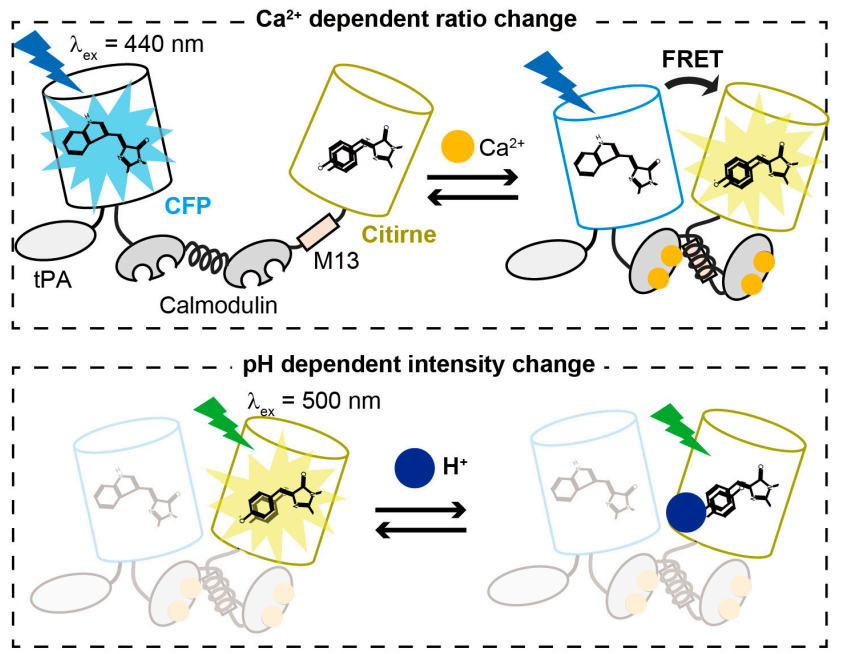

D)

ClopHensor (non-FRET-based $\mathrm{Cl}^{-}$and $\mathrm{H}^{+}$sensor)
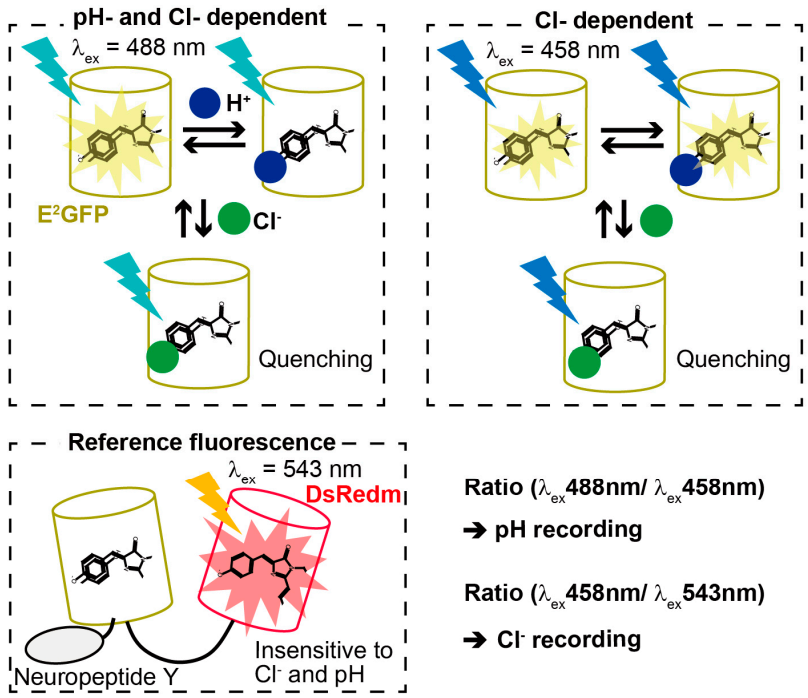

Ratio $\left(\lambda_{\mathrm{ex}} 488 \mathrm{~nm} / \lambda_{\mathrm{ex}} 458 \mathrm{~nm}\right)$

$\rightarrow \mathrm{pH}$ recording

Ratio $\left(\lambda_{\mathrm{ex}} 458 \mathrm{~nm} / \lambda_{\mathrm{ex}} 543 \mathrm{~nm}\right)$

$\rightarrow \mathrm{Cl}$ recording

Figure 2. Schematic drawing of FP-based sensors for application in acidic organelles. (A) mKeima emits single emission at $620 \mathrm{~nm}$, with dual excitation peaks at 438 and $550 \mathrm{~nm}$, corresponding to protonated and deprotonated state of the chromophore. Under starvation-induced autophagy LC3-tagged mKeima is incorporated into autophagosomes, then recruited into lysosomes. This acidification induces color change of mKeima. LC3: microtubule-associated protein light chain 3; (B) D1-SG is a FRET-based and low-affinity $\mathrm{Ca}^{2+}$ sensor applicable at $\mathrm{pH}$ levels between 5.5 and $7.4\left(K_{\mathrm{d}} \sim 120-190 \mu \mathrm{M}\right)$. Citrine can serve as an intentiometric $\mathrm{pH}$ sensor with direct excitation of $\sim 500 \mathrm{~nm}$, due to its inherent $\mathrm{pH}$ sensitivity $\left(\mathrm{p} K_{\mathrm{a}}=5.8\right)$. tPA: tissue plasminogen activator (secretory granule localization); (C) eZinCh is FRET-based, with low-affinity $\mathrm{Zn}^{2+}$ sensors composed of Cerulean and Citrine with Cys and His substitutions directed outside the $\beta$-barrel. Simultaneous use with $\mathrm{pH}$ sensor is necessary for $\mathrm{pH}$ calibration of the sensor. VAMP2: vesicle-associated membrane protein 2 (secretory granule localization); (D) ClopHensor records both $\mathrm{Cl}^{-}$and $\mathrm{pH}$ in a ratiometric manner by applying three lasers for excitation $(458,488$ and $543 \mathrm{~nm})$. E $\mathrm{E}^{2} \mathrm{GFP}$ changes the ratio of two excitation peaks and fluorescence intensity (protonated and deprotonated forms) depending on $\mathrm{Cl}^{-}$concentration and $\mathrm{pH}$. A $\mathrm{pH}$ isosbestic point exists at $\sim 458 \mathrm{~nm}$ so that $\mathrm{E}^{2} \mathrm{GFP}$ emission under $458 \mathrm{~nm}$ excitation is $\mathrm{pH}$-insensitive. 


\section{2. $\mathrm{pH}$ Sensors}

A variety of FP-based $\mathrm{pH}$ sensors have been developed until now, including (1) intensity-based sensors composed of a single FP; (2) ratiometric-based sensors composed of a single FP and (3) FRET-based sensors composed of two FPs. Single FP-based ratiometric pH sensors allow more reliable measurement which is less affected by concentration changes of the sensors, and easy tagging into intracellular organelles because of their smaller size ( $28 \mathrm{kDa})$ compared with FRET-based sensors. Thus, in this section, we mainly introduce some examples of single FP-based ratiometric $\mathrm{pH}$ sensors for $\mathrm{pH}$ measurement in acidic organelles. For details of other types of $\mathrm{pH}$ sensors, see other review articles, such as [55] published in 2013. In addition to various $\mathrm{pH}$ sensors listed in the article, new intentiometric RFP-based $\mathrm{pH}$ sensors, $\mathrm{pHuji}\left(\mathrm{p} K_{\mathrm{a}}=7.7\right.$, Hill coefficient $\left.\left(\mathrm{n}_{\mathrm{H}}\right)=1.10\right)$ and $\mathrm{pHoran} 4$ $\left(\mathrm{p} K_{\mathrm{a}}=7.5\right.$, Hill coefficient $\left.\left(\mathrm{n}_{\mathrm{H}}\right)=0.92\right)$ have recently been reported [56].

mKeima is a large Stokes-shift version of monomeric red FP (Figure 2A) [57,58]. It exhibits a single emission peak $(620 \mathrm{~nm})$ with bimodal excitation spectra ( 438 and $550 \mathrm{~nm}$ peaks), corresponding to neutral (protonated) and anionic (deprotonated) forms of the chromophore, respectively. The ratio of the chromophore's ionized form is dependent on $\mathrm{pH}$ with a $\mathrm{p} K_{\mathrm{a}}$ of 6.5 , thus mKeima can be used as a ratiometric $\mathrm{pH}$ sensor. mKeima also shows high resistance to lysosomal degradation enzymes. Katayama et al. utilized these advantages to develop a sensor to detect autophagic events, specifically conversion of autophagosomes to autolysosomes [58]. To achieve this, they fused mKeima with microtubule-associated protein light chain 3 (LC3). During starvation-induced autophagy, the LC3 undergoes cleavage and phosphatidylethanolamine modification, then being recruited to the outer and inner membrane of autophagosomes. Then, they fuse with lysosomes (autolysosomal maturation), so that the packed cargoes are exposed to an acidic and degradative environment for degradation. The mKeima-LC3 probe enabled visualization of these autolysosomal maturation events by detection of the acidification-induced color change of mKeima, and provided a cumulative fluorescent readout of autophagic activity, which was not possible with previous FPs undergoing acidic or proteolytic quenching in lysosomes. An improved version of the ratiometric dual-excitation $\mathrm{pH}$ sensor, pHRed was later developed from mKeima [59]. The ratio of fluorescence emission under excitation at 440 and $585 \mathrm{~nm}$ changes $>10$-fold dynamic range with an apparent $\mathrm{p} K_{\mathrm{a}}$ of 6.6. $\mathrm{pHRed}$ also exhibits $\mathrm{pH}$-dependent fluorescence lifetime in the range of $\mathrm{pH} 5$ and 8 with near-infrared two-photon excitation. Because near-infrared light has higher light penetration and less light scattering in thick samples, such as brains, two-photon fluorescence lifetime imaging would offer an advantage for deep-tissue $\mathrm{pH}$ monitoring across a broad $\mathrm{pH}$ range.

$\mathrm{E}^{1} \mathrm{GFP}$ is a ratiometric dual emission $\mathrm{pH}$ sensor with a $\mathrm{p} K_{\mathrm{a}}$ of 6.0 [60]. Under excitation at $403 \mathrm{~nm}$, the emission peak shifts from $500 \mathrm{~nm}(\mathrm{pH} \sim 5.0)$ to $523 \mathrm{~nm}(\mathrm{pH} \sim 7.0)$. Although the mechanism is unclear, the authors expect it derives from a different acceptor residue in the ESPT process: presumably the neighboring E222 residue is protonated in low $\mathrm{pH}$ and cannot act as an ESPT acceptor. The utility to measure $\mathrm{pH}$ values in mildly-acidic organelles was demonstrated by fusing it with Trans-activating (Tat) viral protein and monitoring the process of intracellular trafficking after internalization in HeLa cells, which involved $\mathrm{pH}$ changes from $\sim 6.3$ to $\sim 5.8$. 
Table 2. FP-based or chemical dye-based sensors for measurement of ion concentration in acidic organelles.

\begin{tabular}{|c|c|c|c|c|c|c|c|}
\hline Ion & Organelle & Cell & Sensor & Class & $\mathrm{p} K_{\mathrm{a}}$ or $K_{\mathrm{d}}\left(\mathrm{pH}\right.$ or $\left.\mathrm{p} K_{\mathrm{a}}\right)$ & $\begin{array}{c}\text { Resting } \mathrm{pH}, \text { or }\left[\mathrm{Ca}^{2+}, \mathrm{Zn}^{2+} \text { or }\right. \\
\left.\mathrm{Cl}^{-}\right](\mathrm{pH})\end{array}$ & Ref \\
\hline \multirow[t]{11}{*}{$\mathrm{pH}$} & Endosome & Foreskin keratino-cyte & Cellubrevin-r-pHluorin & $\begin{array}{l}\text { Gen a, Single FP-base } \\
\text { dual-excitation }\end{array}$ & $6.9[61]$ & Early endosome: 5.9 & {$[62]$} \\
\hline & & HeLa & Tat-E GFP & $\begin{array}{l}\text { Gen, Single FP-base } \\
\text { dual-excitation }\end{array}$ & $6.4-6.7$ & $\begin{array}{c}\text { Early endosome: } 6.8 \\
\text { Endosome: } 5.8-6.3 \\
\end{array}$ & {$[60]$} \\
\hline & & MIN6 beta-cell & TiVAMP-mKeima & $\begin{array}{c}\text { Gen, Single FP-base } \\
\text { dual-excitation }\end{array}$ & 5.8 & $\begin{array}{l}\text { Early endosome: } 6.3 \\
\text { Late endosome: } 5.8 \\
\end{array}$ & {$[63]$} \\
\hline & Synaptic vesicle (SV) & Hippocam-pal neuron & Synaptophysin-mOrange2 & $\begin{array}{c}\text { Gen, Single FP-base, } \\
\text { intensiometric }\end{array}$ & 6.5 & $\begin{array}{l}\text { GABAergic SV: } \sim 6.4 \\
\text { Glutamatergic SV: } \sim 5.8\end{array}$ & {$[64]$} \\
\hline & Secretory granule & PC12 & $\begin{array}{l}\text { Citrine (YFP) used in D1-SG }\left(\mathrm{Ca}^{2+}\right. \\
\text { sensor) }\end{array}$ & Gen, intensiometric & 5.8 & 5.8 & {$[65]$} \\
\hline & & PC12 & CgA-ECFP & Gen, Single FP-base, FLIM & N.D. & 5.5 & {$[66]$} \\
\hline & & MIN6 & VAMP2-pH.fluorin(e) & $\begin{array}{l}\text { Gen, Single FP-base, } \\
\text { Intensiometric }\end{array}$ & N.D. & 6.3 & {$[67]$} \\
\hline & & PC12, WSS-1 & NPY-ClopHensor & $\begin{array}{l}\text { Gen, Ratiometric } \\
\text { (Non-FRET-base) }\end{array}$ & 6.8 & $\begin{array}{l}5.2 \text { (PC12) } \\
5.6 \text { (WSS1) }\end{array}$ & {$[68]$} \\
\hline & Lysosome & HeLa, MCF-7 & Lyso-pH & Chem $^{\mathrm{b}}$, Ratiometric & 5.0 & 4.6 & {$[69]$} \\
\hline & Vacuole & A. thaliana & Aleurain-PRpHluorin & $\begin{array}{l}\text { Gen, Single FP-base } \\
\text { dual-excitation }\end{array}$ & 6.6 & 5.2 & {$[70]$} \\
\hline & & A. niger & $\begin{array}{l}\mathrm{RaVC} \text { (improved version of } \mathrm{pHluorin} \\
\text { for } \mathrm{pH} \text { imaging in filamentous fungi) }\end{array}$ & $\begin{array}{l}\text { Gen, Single FP-base } \\
\text { dual-excitation }\end{array}$ & $\begin{array}{l}6.7 \text { (in vitro) } \\
6.9 \text { (in cell) }\end{array}$ & $6.2-6.5$ & {$[71]$} \\
\hline \multirow[t]{10}{*}{$\mathrm{Ca}^{2+}$} & Endosome & MIN6 beta-cell & TiVAMP-GEM-GECO1 & $\begin{array}{c}\text { Gen, Single FP-base } \\
\text { dual-emission }\end{array}$ & $\begin{array}{c}0.27(\mathrm{pH} 7.5), 0.46(7.0), 0.68(6.5), 3.1 \\
\quad(6.0), 17.9(5.4), 54.2 \mu \mathrm{M}(5.0)\end{array}$ & $\begin{array}{l}\text { Early endosome: } 0.5 \text { (6.3) } \\
\text { Late endosome: } 2.5 \mu \mathrm{M}(5.8)\end{array}$ & [63] \\
\hline & & 3T3 Swiss fibroblast & Oregon green 488 BAPTA-5N & Chem, Intensiometric & $20 \mu \mathrm{M}$ & $\begin{array}{c}3.0 \mu \mathrm{M}(5.7) \\
\text { (30 min incubation) }\end{array}$ & {$[72]$} \\
\hline & & Pancreatic acinar cell & Oregon green 488 BAPTA-5N & Chem, Intensiometric & $36.5(\mathrm{pH} 7.2), 55.3(5.9), 116 \mu \mathrm{M}(5.3)$ & $37 \mu \mathrm{M}(5.9)$ & {$[73]$} \\
\hline & Secretory granule & PC12 & D1-SG & Gen, FRET-base & $120-190 \mu \mathrm{M}(\mathrm{pH} 7.4-5.5)$ & $69 \mu \mathrm{M}(5.8)$ & {$[65]$} \\
\hline & & MIN6 & VAMP2-mut.aequorin & Gen, Intensiometric & $1-10 \mu \mathrm{M}$ & $\sim 50 \mu \mathrm{M}(6.3)$ & {$[67]$} \\
\hline & & PC12 & Chromogranin-aequorin & Gen, Intensiometric & $3.8 \mu \mathrm{M}[74]$ & $1.4 \mu \mathrm{M}(\sim 5.5)$ & {$[75]$} \\
\hline & & Sea urchin egg & Fluo-4 & Chem, Intensiometric & $345 \mathrm{nM}(\mathrm{pH} 7.2)$ [76] & $\sim 10-100 \mu \mathrm{M}$ & {$[77]$} \\
\hline & Lysosome & Mouse macrophage & Fura-2 dextran & Chem, Ratiometric & $\sim 200 \mu \mathrm{M}$ & $600 \mu \mathrm{M}(4.5)$ & [53] \\
\hline & & Mouse macrophage & Oregon green BAPTA-1 dextran & Chem, Intensiometric & $\sim 500 \mu \mathrm{M}$ & $400 \mu \mathrm{M}(4.5)$ & [53] \\
\hline & & Human fibroblast & Rhod dextran & Chem, Intensiometric & $551 \pm 107 \mu \mathrm{M}$ & $550 \mu \mathrm{M}(4.5)$ & {$[78]$} \\
\hline
\end{tabular}


Table 2. Cont.

\begin{tabular}{|c|c|c|c|c|c|c|c|}
\hline Ion & Organelle & Cell & Sensor & Class & $\mathrm{p} K_{\mathrm{a}}$ or $K_{\mathrm{d}}\left(\mathrm{pH}\right.$ or $\left.\mathrm{p} K_{\mathrm{a}}\right)$ & $\begin{array}{c}\text { Resting } \mathrm{pH}, \text { or }\left[\mathrm{Ca}^{2+}, \mathrm{Zn}^{2+} \text { or }\right. \\
\left.\mathrm{Cl}^{-}\right](\mathrm{pH})\end{array}$ & Ref. \\
\hline \multirow[t]{4}{*}{$\mathrm{Cl}^{-}$} & Endosome & J774 cell, $\mathrm{CHO}$ cell & BAC-TMR-dextran & Chem, Ratiometric & $\sim 25-50 \mathrm{mM}(\mathrm{pH} 7.4)$ & $\begin{array}{c}17 \rightarrow 53 \mathrm{mM}(6.95 \rightarrow 5.30)(\mathrm{J} 773) \\
28 \rightarrow 73 \mathrm{mM}(6.92 \rightarrow 5.60)(\mathrm{CHO})\end{array}$ & [79] \\
\hline & & J774 cell, $\mathrm{CHO}$ cell & BAC-dextran-Tf-TMR & Chem, Ratiometric & $\sim 25-50 \mathrm{mM}(\mathrm{pH} 7.4)$ & $\begin{array}{c}18 \rightarrow 40 \mathrm{mM}(6.91 \rightarrow 6.05)(\mathrm{J} 773) \\
24 \rightarrow 46 \mathrm{mM}(6.95 \rightarrow 6.18)(\mathrm{CHO})\end{array}$ & [80] \\
\hline & Secretory granule & PC12, WSS-1 & NPY-ClopHensor & $\begin{array}{l}\text { Gen, Ratiometric } \\
\text { (Non-FRET-base) }\end{array}$ & $13.1 \mathrm{mM}\left(\mathrm{p} K_{\mathrm{a}} 6.81\right)$ & $\begin{array}{c}110 \pm 48 \mathrm{mM} \text { (5.2) (PC12) } \\
122 \mathrm{mM} \text { (5.6) (WSS1) }\end{array}$ & [68] \\
\hline & Lysosome & Venticular myocyte & 6-methoxyquino-linium-dansyl & Chem, Ratiometric & $\sim 15 \mathrm{mM}(\mathrm{pH} 4.5)$ & $9.46 \mathrm{mM}$ & [81] \\
\hline \multirow[t]{4}{*}{$\mathrm{Zn}^{2+}$} & Secretory granule & INS-1 (832/13) & VAMP2-eZinCh & Gen, Ratiometric (FRET) & $8(\mathrm{pH} 7.1), 260 \mu \mathrm{M}(6.0)$ & $1-100 \mu \mathrm{M}$ & [82] \\
\hline & Lysosome & NIH 3T3 & DQZn4 & Chem, Ratiometric & $16 \mathrm{nM}(\mathrm{pH} 5.2)$ & N.D. & [83] \\
\hline & & NSCs, MCF-7, HeLa & LysoZn-1 & Dhem, Ratiometric & $\sim 150 \mu \mathrm{M}(\mathrm{pH} 7.2)$ & N.D. & [84] \\
\hline & & NIH 3T3 & probe 1 (no name) & Chem, Intensiometric & $8.55 \mu \mathrm{M}(\mathrm{pH} 5.0)$ & N.D. & [85] \\
\hline
\end{tabular}

${ }^{a}$ FP-based sensor; ${ }^{\mathrm{b}}$ Organic dye-based sensor. 


\subsection{Calcium Ion Sensors}

D1-SG is a FRET-based sensor for simultaneous $\mathrm{Ca}^{2+}$ and $\mathrm{pH}$ measurement in secretory granules (Figure 2B) [65]. It was developed from a cameleon [86], which consists of a CFP and a Citrine (YFP) in conjunction with a calmodulin $(\mathrm{CaM})$ insert that contains mutations to lower its $\mathrm{Ca}^{2+}$ affinity along with a CaM-binding peptide (M13) from myosin light-chain kinase. D1-SG also contains a tissue plasminogen activator (tPA) at the N-terminal for localization into secretory granules. In the presence of $\mathrm{Ca}^{2+}$ a CaM changes its conformation to interact with the M13 peptide (the CaM wraps around the M13 peptide). This conformational change renders the distance between the donor CFP and the acceptor Citrine closer, leading to an increase in the FRET efficiency. Surprisingly, $\mathrm{Ca}^{2+}$ affinity is hardly affected by pH changes between pH 7.4 and $5.5\left(K_{\mathrm{d}} \sim 120-190 \mu \mathrm{M}\right)$, however, the FRET ratio value (CFP intensity to Citrine) is variable depending on $\mathrm{pH}$. Therefore, simultaneous recording of $\mathrm{pH}$ values during the FRET measurement are required to calibrate the correct $\mathrm{Ca}^{2+}$ concentration. For use in secretory granules of PC12 cells, Citrine within D1-SG was directly excited to obtain an emission signal whose intensity was dependent on $\mathrm{pH}\left(\mathrm{p} K_{\mathrm{a}}=5.8\right)$ - calibration was achieved by fully alkalizing the secretory granules by treating cells with $\mathrm{NH}_{4} \mathrm{Cl}$ solution $(20 \mathrm{mM})$, whereby maximum emission was achieved. Accordingly, steady state $\mathrm{pH}$ and $\mathrm{Ca}^{2+}$ concentration in the secretory granules of $\mathrm{PC} 12$ cells was calculated as 5.8 and $69 \pm 15 \mu \mathrm{M}$ respectively. In the paper, $\mathrm{Ca}^{2+}$ imaging by using the D1-SG probe suggested important new roles for secretory granules, such as contributors to local cytoplasmic $\mathrm{Ca}^{2+}$ rise and refilling of luminal $\mathrm{Ca}^{2+}$ in the ER.

Single FP-based sensors such as the GCaMP series have been widely used to investigate $\mathrm{Ca}^{2+}$-related signal dynamics in the cytoplasm, especially in the field of neuroscience. GCaMP variants with low affinity to $\mathrm{Ca}^{2+}$, such as CEPIAs $\left(K_{\mathrm{d}} \sim 560-670 \mu \mathrm{M}\right.$ at pH 7.2) [87] and GCaMPer $\left(K_{\mathrm{d}} \sim 400 \mu \mathrm{M}\right.$ at $\mathrm{pH}$ 7.2) [88] have been developed to observe $\mathrm{Ca}^{2+}$ dynamics inside the endoplasmic reticulum. However, the application of most of the GCaMP series to acidic organelles is not currently practical due to their decreased fluorescence intensity at $\mathrm{pH}$ less than 7.0 [89]. Their application to imaging within lysosomes is almost impossible because most of them are not resistant to degradative enzymes. The fluorescence of DsRed and eqFP611-derived RCaMPs show higher resistance to degradation enzymes, although the resistance of the $\mathrm{Ca}^{2+}$-binding domain is not clear [39]. Among them, one good choice as a relatively $\mathrm{pH}$-insensitive GCaMP-type sensor is GEM-GECO, which has been utilized to investigate the concentration and dynamics of $\mathrm{Ca}^{2+}$ in single endosomes $[63,89]$. GEM-GECO is composed of a circular permutant of GFP sandwiched with CaM and the M13 peptide. When excited at $\sim 400 \mathrm{~nm}$, GEM-GECO1 exhibits green $(\sim 510 \mathrm{~nm})$ emission in the absence of $\mathrm{Ca}^{2+}$, and blue $(\sim 450 \mathrm{~nm})$ emission in the presence of $\mathrm{Ca}^{2+}$. The dynamic range of GEM-GECO1 seems mostly unaffected by $\mathrm{pH}$ in the range of $\mathrm{pH} 7.50$ and 5.42, although the $\mathrm{Ca}^{2+}$ affinity is reduced as $\mathrm{pH}$ drops $\left(K_{\mathrm{d}}{ }^{\mathrm{Ca}}=0.27(\mathrm{pH} 7.50)\right.$, 0.46 (pH 7.00), 0.68 ( $\mathrm{pH} 6.50), 3.09$ ( $\mathrm{pH} 6.00), 17.88$ (pH 5.42), $54.24 \mu \mathrm{M}$ ( $\mathrm{pH} 4.97)$ ). In order to correct for $\mathrm{pH}$-dependent effects of the GEM-GECO's $\mathrm{Ca}^{2+}$ affinity in endosomes, the authors used a ratiometric dual-excitation $\mathrm{pH}$ sensor, $\mathrm{mKeima}\left(\mathrm{p} K_{\mathrm{a}}=6.0\right)$. Their semi-quantitative estimation by using the in vitro $K_{\mathrm{d}}$ values suggested that $\mathrm{Ca}^{2+}$ concentration within a majority of endosomes in MIN6 beta-cells is below $2 \mu \mathrm{M}$. $\mathrm{Ca}^{2+}$ concentration in more acidic Rab7-positive late endosomes was higher than that in Rab5a-positive early endosomes. Taken together, these $\mathrm{Ca}^{2+}$ sensors in combination with proper $\mathrm{pH}$ sensors will help researchers elucidate unknown mechanisms and roles of acidic organelles relating to the intracellular $\mathrm{Ca}^{2+}$ signaling network.

\subsection{Zinc Ion Sensors}

eCALWY and eZinCh are FRET-based sensors used to monitor intracellular free $\mathrm{Zn}^{2+}$ concentration (Figure 2C) [82]. For eCALWY, a functional $\mathrm{Zn}^{2+}$ binding domain composed of Atox1 and linked via a long flexible linker to domain 4 of ATP7B is sandwiched by Cerulean (CFP) and Citrine (YFP), both of which show reduced $\mathrm{pH}$ sensitivity. Mutations on both FPs at their dimeric interface (S208F and V224L) promoted an intramolecular interaction which increased FRET from CFP to YFP in the absence of $\mathrm{Zn}^{2+}$, while the interaction (and therefore the FRET) was decreased upon 
$\mathrm{Zn}^{2+}$ binding to the functional domain, leading to a 2.4-fold decrease in the emission ratio value. $K_{\mathrm{d}}$ (pH 7.1) for eCALWY variants $1-6$ is 2, 9, 45, 630, 1850 and $2900 \mathrm{pM}$ respectively, and $K_{\mathrm{d}}(\mathrm{pH}$ 6.0) for VAMP2-eCALWY-6 is $0.5 \mu \mathrm{M}$. For eZinCh, Cerulean and Citrine with mutations (Y39H and S208C) to coordinate $\mathrm{Zn}^{2+}$ at their dimeric interface are connected via a long flexible linker. eZinCh exhibits $K_{\mathrm{d}}$ of $8 \mu \mathrm{M}(\mathrm{pH} 7.1)$ and $250 \mu \mathrm{M}\left(\mathrm{pH}\right.$ 6.0). In the presence of $\mathrm{Zn}^{2+}$, Cerulean and Citrine presumably align in a parallel orientation to bind to $\mathrm{Zn}^{2+}$ at their respective Cys208, and subsequently bind to the $2 \mathrm{nd} \mathrm{Zn}^{2+}$ at their respective His39, resulting in enhanced FRET efficiency [90]. These sensors could be targeted in insulin granules of INS-1 (832/13) cells by fusing them to the C-terminal of vesicle-associated membrane protein2 (VAMP2). As a result, free $\mathrm{Zn}^{2+}$ concentration in these vesicles was estimated at between 1 and $100 \mu \mathrm{M}$.

\subsection{Chloride Ion Sensors}

ClopHensor is a non-FRET-based sensor for simultaneous measurement of intracellular $\mathrm{Cl}^{-}$ concentration and $\mathrm{pH}$ (Figure 2D) [68]. It is composed of $\mathrm{Cl}^{-}$- and $\mathrm{pH}$-sensitive $\mathrm{E}^{2} \mathrm{GFP}$ and $\mathrm{Cl}^{-}$- and $\mathrm{pH}$-insensitive monomeric DsRed (RFP) linked via a long linker. $\mathrm{E}^{2} \mathrm{GFP}$ shows dual excitation spectra ( $\sim 40$ and $510 \mathrm{~nm}$ peaks) originating from neutral and ionic states of the chromophore, where the ratio is dependent on $\mathrm{pH}$ values with an isosbestic point at $458 \mathrm{~nm}$. $\mathrm{E}^{2} \mathrm{GFP}$ also has a $\mathrm{Cl}^{-}$binding pocket in the vicinity of the chromophore imidazolidinone aromatic ring and shows $\mathrm{Cl}^{-}$-dependent changes of the fluorescence properties. $\mathrm{Cl}^{-}$-binding to the protein does not affect the ratio of the neutral and ionic chromophore. Accordingly, (1) $458 \mathrm{~nm}$ excitation at the isosbestic point for $E^{2} \mathrm{GFP}$; (2) $488 \mathrm{~nm}$ excitation for $\mathrm{E}^{2} \mathrm{GFP}$; and (3) $543 \mathrm{~nm}$ excitation for monomeric DsRed generate (1) $\mathrm{Cl}^{-}$-dependent; (2) $\mathrm{pH}$ - and $\mathrm{Cl}^{-}$-dependent; and (3) $\mathrm{pH}$ - and $\mathrm{Cl}^{-}$-independent signals. The $\mathrm{pH}$ calibration curve was

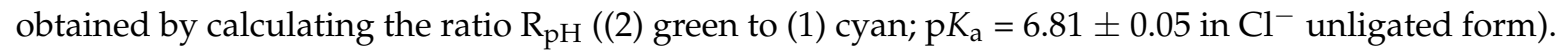
The $\mathrm{pH}$-dependent calibration curve for $\mathrm{Cl}^{-}$concentration was derived from the ratio $\mathrm{R}_{\mathrm{Cl}}((1)$ cyan to (3) red; ${ }^{1} K_{d}{ }^{C l}=13.1 \pm 0.5 \mathrm{mM}$ in $\mathrm{pH}$ 6.9). The authors applied ClopHensor in large dense-core vesicles (LDCVs), the dominant secretory organelles in neuroendocrine cells by fusing to the $\mathrm{N}$-terminal signal sequence of neuropeptide $\mathrm{Y}$ (NPY). They successfully revealed that the average $\mathrm{pH}$ of LCDVs is $5.2 \pm 0.4$ and the average $\mathrm{Cl}^{-}$concentration is $110 \pm 48 \mathrm{mM}$ (mean \pm s.d.).

\section{Conclusions and Future Prospective}

A variety of acid-tolerant FPs $\left(\mathrm{pK}_{\mathrm{a}}<4.0\right)$ with a wide color-range of excitation and emission spectra have been developed. These provide researchers with more options to perform multicolor imaging and develop single FP-based and FRET-based sensors to elucidate molecular or ionic mechanisms in acidic cellular environments [91]. Many different ions inside acidic organelles play important roles during regulation of the activity of internal proteins, cellular signaling and biological homeostasis. To investigate their functions, several ion sensors $\left(\mathrm{Ca}^{2+}, \mathrm{Zn}^{2+}\right.$ and $\left.\mathrm{Cl}^{-}\right)$have been developed and applied in acidic organelles. As we discussed in Section 3, simultaneous use of a $\mathrm{pH}$ sensor for $\mathrm{pH}$ calibration is essential for quantitative measurement. In order to avoid spectral overlap, good combinations of ion and $\mathrm{pH}$ sensor are as follows: (1) a FRET-based ion sensor composed of CFP and GFP (or YFP), and an intentiometric or ratiometric $\mathrm{pH}$ sensor composed of a single RFP (e.g., mOrange2, mKeima and pHRed [40,57,59]); (2) a ratiometric ion sensor composed of a single GFP (or YFP), and an intentiometric or ratiometric $\mathrm{pH}$ sensor composed of a single RFP; (3) a ratiometric ion sensor composed of a single RFP, and an intentiometric or ratiometric $\mathrm{pH}$ sensor composed of a single GFP (e.g., $\mathrm{mNeonGreen} \mathrm{and} \mathrm{E}^{1} \mathrm{GFP}[37,60]$ ); (4) a FRET-based ion sensor in which acceptor fluorescence is $\mathrm{pH}$ sensitive upon direct excitation (e.g., D1-SG, Figure 2B [65]); (5) an exceptional $\mathrm{FP}$ which shows bimodal excitation (or emission) spectra sensitive to both specific ion and $\mathrm{pH}$ (e.g., ClopHensor, Figure 2D [68]), and a FP insensitive to both the ion and $\mathrm{pH}$ which is used as reference fluorescence for ratiometric measurement.

Among the various ion species in acidic organelles, in particular $\mathrm{Ca}^{2+}$-mediated communication between acidic organelles and neutral $\mathrm{pH}$ organelles, as well as signaling network activation triggered 
by $\mathrm{Ca}^{2+}$ release from acidic organelles in both mammalian and plant cells have recently become areas of increased interest for researchers [4]. The vacuole is the largest and acidic $\mathrm{Ca}^{2+}$-store in plant cells, which may contribute to broad $\mathrm{Ca}^{2+}$ signaling, however, precious few functional roles have been directly demonstrated [92]. The development of $\mathrm{Ca}^{2+}$ sensors with less $\mathrm{pH}$ sensitivity would be highly useful for investigating these temporal and spatial dynamics. New types of FP-based sensors to monitor cytosolic $\mathrm{K}^{+}$(GEPIIs and KIRIN-1 $[93,94]$ ) and $\mathrm{Mg}^{2+}$ concentration (MagFRET and MARIO $[95,96])$ have recently been published. Improvement of these sensors to facilitate their application to acidic cellular environments may help to reveal heretofore unknown functions (e.g., ion homeostasis, ionic gradients or potential across the membrane, and subsequent biological events). Sensors to detect amino acids such as glutamate (SuperGluSnFR, iGluSnFR, iGlu $\mathrm{f}_{\mathrm{f}}$ and $\mathrm{iGlu}_{\mathrm{u}}$ [97-99]) and arginine (QBP/Citrine/ECFP [100]) have also been reported. The development of such sensors for acidic environments would be useful, especially in the case of glutamate release from synaptic vesicles ( $\mathrm{pH} \sim 5.8$ [64]) into the synaptic cleft, which induces neural excitation; the concentration and turnover rate of glutamate into the synaptic vesicles would help in the study of synaptogenesis. The development of a lysosomal arginine sensor would be useful to unveil potential connections between arginine concentration in lysosomes and the autophagy-related signaling pathway [101]. As an alternative application for imaging with acid-tolerant FPs, the development of new acid-tolerant chemiluminescent proteins (CPs) will also expand choices for researchers: CPs can overcome flaws inherent to FPs due to their requirement for excitation light including autofluorescence from samples, undesired activation of light-dependent biological process such as photoreception, and incompatibility with optogenetic tools due to their spectral overlap [102]. To date, there are no acid-tolerant CPs optimized for imaging application. Protein engineering of unique dinoflagellate-derived CPs which emit strong luminescence in acidic conditions [103], or searching for new CPs from uncharacterized bioluminescent species will fulfill these niche but necessary demands of researchers in the future.

Acknowledgments: This work was supported by the 'CREST, JST' (No. JPMJCR15N3, JPMJCR12M6), and the MEXT 'Grant-in-Aid for Scientific Research on Innovative Areas' 'Spying minority in biological phenomena' (No. JP23115003).

Conflicts of Interest: The authors declare no conflict of interest.

\section{References}

1. Huotari, J.; Helenius, A. Endosome maturation. EMBO J. 2011, 30, 3481-3500. [CrossRef] [PubMed]

2. Settembre, C.; Fraldi, A.; Medina, D.L.; Ballabio, A. Signals from the lysosome: A control centre for cellular clearance and energy metabolism. Nat. Rev. Mol. Cell Biol. 2013, 14, 283-296. [CrossRef] [PubMed]

3. Turk, B.; Turk, V. Lysosomes as "suicide bags" in cell death: Myth or reality? J. Biol. Chem. 2009, 284, 21783-21787. [CrossRef] [PubMed]

4. Patel, S.; Docampo, R. Acidic calcium stores open for business: Expanding the potential for intracellular $\mathrm{Ca}^{2+}$ signaling. Trends Cell Biol. 2010, 20, 277-286. [CrossRef] [PubMed]

5. Stauber, T.; Jentsch, T.J. Chloride in Vesicular Trafficking and Function. Annu. Rev. Physiol. 2013, 75, 453-477. [CrossRef] [PubMed]

6. Zoncu, R.; Bar-Peled, L.; Efeyan, A.; Wang, S.; Sancak, Y.; Sabatini, D.M. mTORC1 senses lysosomal amino acids through an inside-out mechanism that requires the vacuolar $\mathrm{H}^{+}$-ATPase. Science 2011, 334, 678-683. [CrossRef] [PubMed]

7. Tsien, R.Y. The Green Fluorescent Proteins. Annu. Rev. Biochem. 1998, 67, 509-544. [CrossRef] [PubMed]

8. Cranfill, P.J.; Sell, B.R.; Baird, M.A.; Allen, J.R.; Lavagnino, Z.; De Gruiter, H.M.; Kremers, G.; Davidson, M.W.; Ustione, A.; Piston, D.W. Quantitative assessment of fluorescent proteins. Nat. Methods 2016, 13, 557-562. [CrossRef] [PubMed]

9. Masuda, H.; Takenaka, Y.; Yamaguchi, A.; Nishikawa, S.; Mizuno, H. A novel yellowish-green fluorescent protein from the marine copepod, Chiridius poppei, and its use as a reporter protein in HeLa cells. Gene 2006, 372, 18-25. [CrossRef] [PubMed] 
10. Bomati, E.K.; Haley, J.E.; Noel, J.P.; Deheyn, D.D. Spectral and structural comparison between bright and dim green fluorescent proteins in Amphioxus. Sci. Rep. 2014, 4, 5469. [CrossRef] [PubMed]

11. Matz, M.V.; Fradkov, A.F.; Labas, Y.A.; Savitsky, A.P.; Zaraisky, A.G.; Markelov, M.L.; Lukyanov, S.A. Fluorescent proteins from nonbioluminescent Anthozoa species. Nat. Biotechnol. 1999, 17, 969-973. [CrossRef] [PubMed]

12. Shinoda, H.; Ma, Y.; Nakashima, R.; Sakurai, K.; Matsuda, T.; Nagai, T. Acid-Tolerant Monomeric GFP from Olindias formosa. Cell Chem. Biol. 2018, 25, 330-338. [CrossRef] [PubMed]

13. Campbell, R.E.; Tour, O.; Palmer, A.E.; Steinbach, P.A.; Baird, G.S.; Zacharias, D.A.; Tsien, R.Y. A monomeric red fluorescent protein. Proc. Natl. Acad. Sci. USA 2002, 99, 7877-7882. [CrossRef] [PubMed]

14. Shaner, N.C.; Campbell, R.E.; Steinbach, P.A.; Giepmans, B.N.G.; Palmer, A.E.; Tsien, R.Y. Improved monomeric red, orange and yellow fluorescent proteins derived from Discosoma sp. red fluorescent protein. Nat. Biotechnol. 2004, 22, 1567-1572. [CrossRef] [PubMed]

15. Shen, Y.; Chen, Y.; Wu, J.; Shaner, N.C.; Campbell, R.E. Engineering of mCherry variants with long Stokes shift, red-shifted fluorescence, and low cytotoxicity. PLoS ONE 2017, 12, e0171257. [CrossRef] [PubMed]

16. Bindels, D.S.; Haarbosch, L.; Van Weeren, L.; Postma, M.; Wiese, K.E.; Mastop, M.; Aumonier, S.; Gotthard, G.; Royant, A.; Hink, M.A.; et al. mScarlet: A bright monomeric red fluorescent protein for cellular imaging. Nat. Methods 2016, 14, 53-56. [CrossRef] [PubMed]

17. Wang, L.; Jackson, W.C.; Steinbach, P.A.; Tsien, R.Y. Evolution of new nonantibody proteins via iterative somatic hypermutation. Proc. Natl. Acad. Sci. USA 2004, 101, 16745-16749. [CrossRef] [PubMed]

18. Kredel, S.; Oswald, F.; Nienhaus, K.; Deuschle, K.; Röcker, C.; Wolff, M.; Heilker, R.; Nienhaus, G.U.; Wiedenmann, J. mRuby, a bright monomeric red fluorescent protein for labeling of subcellular structures. PLoS ONE 2009, 4, e4391. [CrossRef] [PubMed]

19. Lam, A.J.; St-Pierre, F.; Gong, Y.; Marshall, J.D.; Cranfill, P.J.; Baird, M.A.; McKeown, M.R.; Wiedenmann, J.; Davidson, M.W.; Schnitzer, M.J.; et al. Improving FRET dynamic range with bright green and red fluorescent proteins. Nat. Methods 2012, 9, 1005-1012. [CrossRef] [PubMed]

20. Bajar, B.T.; Wang, E.S.; Lam, A.J.; Kim, B.B.; Jacobs, C.L.; Howe, E.S.; Davidson, M.W.; Lin, M.Z.; Chu, J. Improving brightness and photostability of green and red fluorescent proteins for live cell imaging and FRET reporting. Sci. Rep. 2016, 6, 20889. [CrossRef] [PubMed]

21. Merzlyak, E.M.; Goedhart, J.; Shcherbo, D.; Bulina, M.E.; Shcheglov, A.S.; Fradkov, A.F.; Gaintzeva, A.; Lukyanov, K.A.; Lukyanov, S.; Gadella, T.W.J.; et al. Bright monomeric red fluorescent protein with an extended fluorescence lifetime. Nat. Methods 2007, 4, 555-557. [CrossRef] [PubMed]

22. Piatkevich, K.D.; Malashkevich, V.N.; Morozova, K.S.; Nemkovich, N.A.; Almo, S.C.; Verkhusha, V.V. Extended stokes shift in fluorescent proteins: Chromophore-protein interactions in a near-infrared TagRFP675 variant. Sci. Rep. 2013, 3, 1847. [CrossRef] [PubMed]

23. Shemiakina, I.I.; Ermakova, G.V.; Cranfill, P.J.; Baird, M.A.; Evans, R.A.; Souslova, E.A.; Staroverov, D.B.; Gorokhovatsky, A.Y.; Putintseva, E.V.; Gorodnicheva, T.V.; et al. A monomeric red fluorescent protein with low cytotoxicity. Nat. Commun. 2012, 3, 1204-1207. [CrossRef] [PubMed]

24. Zapata-Hommer, O.; Griesbeck, O. Efficiently folding and circularly permuted variants of the Sapphire mutant of GFP. BMC Biotechnol. 2003, 3, 5. [CrossRef] [PubMed]

25. Piatkevich, K.D.; Hulit, J.; Subach, O.M.; Wu, B.; Abdulla, A.; Segall, J.E.; Verkhusha, V.V. Monomeric red fluorescent proteins with a large Stokes shift. Proc. Natl. Acad. Sci. USA 2010, 107, 5369-5374. [CrossRef] [PubMed]

26. Piatkevich, K.D.; Malashkevich, V.M.; Almo, S.C.; Verkhusha, V.V. Engineering ESPT pathway based on structural analysis of LSSmKate red fluorescent proteins with large Stokes shift. J. Am. Chem. Soc. 2010, 132, 10762-10770. [CrossRef] [PubMed]

27. Tomosugi, W.; Matsuda, T.; Tani, T.; Nemoto, T.; Kotera, I.; Saito, K.; Horikawa, K.; Nagai, T. An ultramarine fluorescent protein with increased photostability and $\mathrm{pH}$ insensitivity. Nat. Methods 2009, 6, 351-353. [CrossRef] [PubMed]

28. Subach, O.M.; Cranfill, P.J.; Davidson, M.W.; Verkhusha, V.V. An enhanced monomeric blue fluorescent protein with the high chemical stability of the chromophore. PLoS ONE 2011, 6, e28674. [CrossRef] [PubMed]

29. Katayama, H.; Yamamoto, A.; Mizushima, N.; Yoshimori, T.; Miyawaki, A. GFP-like Proteins Stably Accumulate in Lysosomes. Cell Struct. Funct. 2008, 33, 1-12. [CrossRef] [PubMed] 
30. Goedhart, J.; Von Stetten, D.; Noirclerc-Savoye, M.; Lelimousin, M.; Joosen, L.; Hink, M.A.; Van Weeren, L.; Gadella, T.W.J.; Royant, A. Structure-guided evolution of cyan fluorescent proteins towards a quantum yield of 93\%. Nat. Commun. 2012, 3, 751. [CrossRef] [PubMed]

31. Markwardt, M.L.; Kremers, G.J.; Kraft, C.A.; Ray, K.; Cranfill, P.J.C.; Wilson, K.A.; Day, R.N.; Wachter, R.M.; Davidson, M.W.; Rizzo, M.A. An improved cerulean fluorescent protein with enhanced brightness and reduced reversible photoswitching. PLoS ONE 2011, 6, e17896. [CrossRef] [PubMed]

32. Ai, H.; Henderson, J.N.; Remington, S.J.; Campbell, R.E. Directed evolution of a monomeric, bright and photostable version of Clavularia cyan fluorescent protein: Structural characterization and applications in fluorescence imaging. Biochem. J. 2006, 400, 531-540. [CrossRef] [PubMed]

33. Sawano, A.; Miyawaki, A. Directed evolution of green fluorescent protein by a new versatile PCR strategy for site-directed and semi-random mutagenesis. Nucleic Acids Res. 2000, 28, e78. [CrossRef] [PubMed]

34. Shaner, N.C.; Patterson, G.H.; Davidson, M.W. Advances in fluorescent protein technology. J. Cell Sci. 2007, 120, 4247-4260. [CrossRef] [PubMed]

35. Roberts, T.M.; Rudolf, F.; Meyer, A.; Pellaux, R.; Whitehead, E.; Panke, S.; Held, M. Identification and Characterisation of a pH-stable GFP. Sci. Rep. 2016, 6, 28166. [CrossRef] [PubMed]

36. Nagai, T.; Ibata, K.; Park, E.S.; Kubota, M.; Mikoshiba, K.; Miyawaki, A. A variant of YFP with fast and efficient maturation for cell-biological applications. Nat. Biotechnol. 2002, 20, 1585-1588. [CrossRef] [PubMed]

37. Shaner, N.C.; Lambert, G.G.; Chammas, A.; Ni, Y.; Cranfill, P.J.; Baird, M.A.; Sell, B.R.; Allen, J.R.; Day, R.N.; Israelsson, M.; et al. A bright monomeric green fluorescent protein derived from Branchiostoma lanceolatum. Nat. Methods 2013, 10, 407-409. [CrossRef] [PubMed]

38. Tsutsui, H.; Karasawa, S.; Okamura, Y.; Miyawaki, A. Improving membrane voltage measurements using FRET with new fluorescent proteins. Nat. Methods 2008, 5, 683-685. [CrossRef] [PubMed]

39. Shen, Y.; Dana, H.; Abdelfattah, A.S.; Patel, R.; Shea, J.; Molina, R.S.; Rawal, B.; Rancic, V.; Chang, Y.F.; Wu, L.; et al. A genetically encoded $\mathrm{Ca}^{2+}$ indicator based on circularly permutated sea anemone red fluorescent protein eqFP578. BMC Biol. 2018, 16, 9. [CrossRef] [PubMed]

40. Shaner, N.C.; Lin, M.Z.; McKeown, M.R.; Steinbach, P.A.; Hazelwood, K.L.; Davidson, M.W.; Tsien, R.Y. Improving the photostability of bright monomeric orange and red fluorescent proteins. Nat. Methods 2008, 5, 545-551. [CrossRef] [PubMed]

41. Guan, Y.; Meurer, M.; Raghavan, S.; Rebane, A.; Lindquist, J.R.; Santos, S.; Kats, I.; Davidson, M.W.; Mazitschek, R.; Hughes, T.E.; et al. Live-cell multiphoton fluorescence correlation spectroscopy with an improved large Stokes shift fluorescent protein. Mol. Biol. Cell 2015, 26, 2054-2066. [CrossRef] [PubMed]

42. Stiel, A.C.; Trowitzsch, S.; Weber, G.; Andresen, M.; Eggeling, C.; Hell, S.W.; Jakobs, S.; Wahl, M.C. 1.8 A bright-state structure of the reversibly switchable fluorescent protein Dronpa guides the generation of fast switching variants. Biochem. J. 2007, 402, 35-42. [CrossRef] [PubMed]

43. Evdokimov, A.G.; Pokross, M.E.; Egorov, N.S.; Zaraisky, A.G.; Yampolsky, I.V.; Merzlyak, E.M.; Shkoporov, A.N.; Sander, I.; Lukyanov, K.A.; Chudakov, D.M. Structural basis for the fast maturation of Arthropoda green fluorescent protein. EMBO Rep. 2006, 7, 1006-1012. [CrossRef] [PubMed]

44. Shinobu, A.; Agmon, N. The hole in the barrel: Water exchange at the GFP chromophore. J. Phys. Chem. B 2015, 119, 3464-3478. [CrossRef] [PubMed]

45. Pletnev, S.; Gurskaya, N.G.; Pletneva, N.V.; Lukyanov, K.A.; Chudakov, D.M.; Martynov, V.I.; Popov, V.O.; Kovalchuk, M.V.; Wlodawer, A.; Dauter, Z.; et al. Structural basis for phototoxicity of the genetically encoded photosensitizer KillerRed. J. Biol. Chem. 2009, 284, 32028-32039. [CrossRef] [PubMed]

46. Verkhusha, V.V.; Akovbian, N.A.; Efremenko, E.N.; Varfolomeyev, S.D.; Vrzheshch, P.V. Kinetic analysis of maturation and denaturation of DsRed, a coral- derived red fluorescent protein. Biochemistry 2001, 66, 1342-1351. [PubMed]

47. Huang, L.; Pike, D.; Sleat, D.E.; Nanda, V.; Lobel, P. Potential pitfalls and solutions for use of fluorescent fusion proteins to study the lysosome. PLoS ONE 2014, 9, e88893. [CrossRef] [PubMed]

48. Smith, N.A.; Kress, B.T.; Lu, Y.; Chandler-Militello, D.; Benraiss, A.; Nedergaard, M. Fluorescent Ca ${ }^{2+}$ indicators directly inhibit the Na,K-ATPase and disrupt cellular functions. Sci. Signal 2018, 11, eaal2039. [CrossRef] [PubMed]

49. Kuroki, S.; Yoshida, T.; Tsutsui, H.; Iwama, M.; Ando, R.; Michikawa, T.; Miyawaki, A.; Ohshima, T.; Itohara, S. Excitatory Neuronal Hubs Configure Multisensory Integration of Slow Waves in Association Cortex. Cell Rep. 2018, 22, 2809-2817. [CrossRef] [PubMed] 
50. Nick Pace, C.; Scholtz, J.M.; Grimsley, G.R. Forces stabilizing proteins. FEBS Lett. 2014, 588, $2177-2184$. [CrossRef] [PubMed]

51. Casey, J.R.; Grinstein, S.; Orlowski, J. Sensors and regulators of intracellular pH. Nat. Rev. Mol. Cell Biol. 2010, 11, 50-61. [CrossRef] [PubMed]

52. Zhou, J.; Tan, S.H.; Nicolas, V.; Bauvy, C.; Di Yang, N.; Zhang, J.; Xue, Y.; Codogno, P.; Shen, H.M. Activation of lysosomal function in the course of autophagy via mTORC1 suppression and autophagosome-lysosome fusion. Cell Res. 2013, 23, 508-523. [CrossRef] [PubMed]

53. Christensen, K.A.; Myers, J.T.; Swanson, J.A. pH-dependent regulation of lysosomal calcium in macrophages. J. Cell Sci. 2002, 115, 599-607. [PubMed]

54. Steinberg, B.E.; Huynh, K.K.; Brodovitch, A.; Jabs, S.; Stauber, T.; Jentsch, T.J.; Grinstein, S. A cation counterflux supports lysosomal acidification. J. Cell Biol. 2010, 189, 1171-1186. [CrossRef] [PubMed]

55. Benčina, M. Illumination of the Spatial Order of Intracellular $\mathrm{pH}$ by Genetically Encoded pH-Sensitive Sensors. Sensors 2013, 13, 16736-16758. [CrossRef] [PubMed]

56. Shen, Y.; Rosendale, M.; Campbell, R.E.; Perrais, D. pHuji, a pH-sensitive red fluorescent protein for imaging of exo- and endocytosis. J. Cell Biol. 2014, 207, 419-432. [CrossRef] [PubMed]

57. Kogure, T.; Karasawa, S.; Araki, T.; Saito, K.; Kinjo, M.; Miyawaki, A. A fluorescent variant of a protein from the stony coral Montipora facilitates dual-color single-laser fluorescence cross-correlation spectroscopy. Nat. Biotechnol. 2006, 24, 577-581. [CrossRef] [PubMed]

58. Katayama, H.; Kogure, T.; Mizushima, N.; Yoshimori, T.; Miyawaki, A. A sensitive and quantitative technique for detecting autophagic events based on lysosomal delivery. Chem. Biol. 2011, 18, 1042-1052. [CrossRef] [PubMed]

59. Tantama, M.; Hung, Y.P.; Yellen, G. Imaging intracellular $\mathrm{pH}$ in live cells with a genetically encoded red fluorescent protein sensor. J. Am. Chem. Soc. 2011, 133, 10034-10037. [CrossRef] [PubMed]

60. Serresi, M.; Bizzarri, R.; Cardarelli, F.; Beltram, F. Real-time measurement of endosomal acidification by a novel genetically encoded biosensor. Anal. Bioanal. Chem. 2009, 393, 1123-1133. [CrossRef] [PubMed]

61. Miesenböck, G.; De Angelis, D.A.; Rothman, J.E. Visualizing secretion and synaptic transmission with pH-sensitive green fluorescent proteins. Nature 1998, 394, 192-195. [CrossRef] [PubMed]

62. Disbrow, G.L.; Hanover, J.A.; Schlegel, R. Endoplasmic Reticulum-Localized Human Papillomavirus Type 16 E5 Protein Alters Endosomal pH but Not trans -Golgi pH Endoplasmic Reticulum-Localized Human Papillomavirus Type 16 E5 Protein Alters Endosomal pH but Not trans -Golgi pH. J. Virol. 2005, 79, 5839-5846. [CrossRef] [PubMed]

63. Albrecht, T.; Zhao, Y.; Nguyen, T.H.; Campbell, R.E.; Johnson, J.D. Fluorescent biosensors illuminate calcium levels within defined beta-cell endosome subpopulations. Cell Calcium 2015, 57, 263-274. [CrossRef] [PubMed]

64. Egashira, Y.; Takase, M.; Watanabe, S.; Ishida, J.; Fukamizu, A.; Kaneko, R.; Yanagawa, Y.; Takamori, S. Unique $\mathrm{pH}$ dynamics in GABAergic synaptic vesicles illuminates the mechanism and kinetics of GABA loading. Proc. Natl. Acad. Sci. USA 2016, 113, 10702-10707. [CrossRef] [PubMed]

65. Dickson, E.J.; Duman, J.G.; Moody, M.W.; Chen, L.; Hille, B. Orai-STIM-mediated Ca ${ }^{2+}$ release from secretory granules revealed by a targeted $\mathrm{Ca}^{2+}$ and $\mathrm{pH}$ probe. Proc. Natl. Acad. Sci. USA 2012, 109, E3539-E3548. [CrossRef] [PubMed]

66. Poëa-Guyon, S.; Pasquier, H.; Mérola, F.; Morel, N.; Erard, M. The enhanced cyan fluorescent protein: A sensitive $\mathrm{pH}$ sensor for fluorescence lifetime imaging. Anal. Bioanal. Chem. 2013, 405, 3983-3987. [CrossRef] [PubMed]

67. Mitchell, K.J.; Pinton, P.; Varadi, A.; Tacchetti, C.; Ainscow, E.K.; Pozzan, T.; Rizzuto, R.; Rutter, G.A. Dense core secretory vesicles revealed as a dynamic $\mathrm{Ca}^{2+}$ store in neuroendocrine cells with a vesicle-associated membrane protein aequorin chimaera. J. Cell Biol. 2001, 155, 41-51. [CrossRef] [PubMed]

68. Arosio, D.; Ricci, F.; Marchetti, L.; Gualdani, R.; Albertazzi, L.; Beltram, F. Simultaneous intracellular chloride and $\mathrm{pH}$ measurements using a GFP-based sensor. Nat. Methods 2010, 7, 516-518. [CrossRef] [PubMed]

69. Wan, Q.; Chen, S.; Shi, W.; Li, L.; Ma, H. Lysosomal pH rise during heat shock monitored by a lysosome-targeting near-infrared ratiometric fluorescent probe. Angew. Chem. Int. Ed. 2014, 53, 10916-10920. [CrossRef] [PubMed]

70. Shen, J.; Zeng, Y.; Zhuang, X.; Sun, L.; Yao, X.; Pimpl, P.; Jiang, L. Organelle pH in the arabidopsis endomembrane system. Mol. Plant 2013, 6, 1419-1437. [CrossRef] [PubMed] 
71. Bagar, T.; Altenbach, K.; Read, N.D.; Benčina, M. Live-cell imaging and measurement of intracellular $\mathrm{pH}$ in filamentous fungi using a genetically encoded ratiometric probe. Eukaryot. Cell 2009, 8, 703-712. [CrossRef] [PubMed]

72. Gerasimenko, J.V.; Tepikin, A.V.; Petersen, O.H.; Gerasimenko, O.V. Calcium uptake via endocytosis with rapid release from acidifying endosomes. Curr. Biol. 1998, 8, 1335-1338. [CrossRef]

73. Sherwood, M.W.; Prior, I.A.; Voronina, S.G.; Barrow, S.L.; Woodsmith, J.D.; Gerasimenko, O.V.; Petersen, O.H.; Tepikin, A.V. Activation of trypsinogen in large endocytic vacuoles of pancreatic acinar cells. Proc. Natl. Acad. Sci. USA 2007, 104, 5674-5679. [CrossRef] [PubMed]

74. Rossier, J.; Tricoire, L.; Tsuzuki, K.; Courjean, O.; Gibelin, N.; Lambolez, B. Calcium dependence of aequorin bioluminescence dissected by random mutagenesis. Proc. Natl. Acad. Sci. USA 2006, 103, 9500-9505. [CrossRef]

75. Mahapatra, N.R.; Mahata, M.; Hazra, P.P.; Mcdonough, P.M.; Connor, D.T.O.; Mahata, S.K. A Dynamic Pool of Calcium in Catecholamine Storage Vesicles. J. Biol. Chem. 2004, 279, 51107-51121. [CrossRef] [PubMed]

76. Gee, K.R.; Brown, K.A.; Chen, W.U.; Gray, D.; Johnson, I. Chemical and physiological characterization of fluo-4 Ca ${ }^{2+}$-indicator dyes. Cell Calcium 2000, 27, 97-106. [CrossRef] [PubMed]

77. Raveh, A.; Valitsky, M.; Shani, L.; Coorssen, J.R.; Blank, P.S.; Zimmerberg, J.; Rahamimoff, R. Cell Calcium Observations of calcium dynamics in cortical secretory vesicles. Cell Calcium 2012, 52, 217-225. [CrossRef] [PubMed]

78. Lloyd-Evans, E.; Morgan, A.J.; He, X.; Smith, D.A.; Elliot-Smith, E.; Sillence, D.J.; Churchill, G.C.; Schuchman, E.H.; Galione, A.; Platt, F.M. Niemann-Pick disease type C1 is a sphingosine storage disease that causes deregulation of lysosomal calcium. Nat. Med. 2008, 14, 1247-1255. [CrossRef] [PubMed]

79. Sonawane, N.D.; Thiagarajah, J.R.; Verkman, A.S. Chloride Concentration in Endosomes Measured Using a Ratioable Fluorescent $\mathrm{Cl}^{-}$Indicator. J. Biol. Chem. 2002, 277, 5506-5513. [CrossRef] [PubMed]

80. Sonawane, N.D.; Verkman, A.S. Determinants of $\left[\mathrm{Cl}^{-}\right]$in recycling and late endosomes and Golgi complex measured using fluorescent ligands. J. Cell Biol. 2003, 160, 1129-1138. [CrossRef] [PubMed]

81. Li, P.; Zhang, S.; Fan, N.; Xiao, H.; Zhang, W.; Zhang, W.; Wang, H. Quantitative Fluorescence Ratio Imaging of Intralysosomal Chloride Ions with Single Excitation/Dual Maximum Emission. Chemistry 2014, 20, 11760-11767. [CrossRef] [PubMed]

82. Vinkenborg, J.L.; Nicolson, T.J.; Bellomo, E.A.; Koay, M.S.; Rutter, G.A.; Merkx, M. Genetically encoded FRET sensors to monitor intracellular $\mathrm{Zn}^{2+}$ homeostasis. Nat. Methods 2009, 6, 737-740. [CrossRef] [PubMed]

83. Xue, L.; Li, G.; Zhu, D.; Liu, Q.; Jiang, H. Rational Design of a Ratiometric and Targetable Fluorescent Probe for Imaging Lysosomal Zinc Ions. Inorg. Chem. 2012, 51, 10842-10849. [CrossRef] [PubMed]

84. Zhu, H.; Fan, J.; Zhang, S.; Cao, J.; Song, K.; Ge, D.; Dong, H.; Wang, J.; Peng, X. Ratiometric fluorescence imaging of lysosomal $\mathrm{Zn}^{2+}$ release under oxidative stress in stem cells. Biomater. Sci. 2014, 89-97. [CrossRef]

85. Lee, H.; Cho, C.; Seo, H.; Singha, S.; Jun, Y.W.; Lee, K.; Jung, Y.; Kim, K.; Park, S.; Bae, S.C.; et al. A two-photon fluorescent probe for lysosomal zinc ions. Chem. Commun. 2016, 52, 124-127. [CrossRef] [PubMed]

86. Miyawaki, A.; Llopis, J.; Heim, R.; McCaffery, J.M.; Adams, J.A.; Ikura, M.; Tsien, R.Y. Fluorescent indicators for $\mathrm{Ca}^{2+}$ based on green fluorescent proteins and calmodulin. Nature 1997, 388, 882-887. [CrossRef] [PubMed]

87. Suzuki, J.; Kanemaru, K.; Ishii, K.; Ohkura, M.; Okubo, Y.; Iino, M. Imaging intraorganellar Ca ${ }^{2+}$ at subcellular resolution using CEPIA. Nat. Commun. 2014, 5, 4153. [CrossRef] [PubMed]

88. Henderson, M.J.; Baldwin, H.A.; Werley, C.A.; Boccardo, S.; Whitaker, L.R.; Yan, X.; Holt, G.T.; Schreiter, E.R.; Looger, L.L.; Cohen, A.E.; et al. A low affinity GCaMP3 variant (GCaMPer) for imaging the endoplasmic reticulum calcium store. PLoS ONE 2015, 10, e0139273. [CrossRef] [PubMed]

89. Zhao, Y.; Araki, S.; Wu, J.; Teramoto, T.; Chang, Y.; Nakano, M.; Abdelfattah, A.S.; Fujiwara, M.; Ishihara, T.; Nagai, T.; Campbell, R.E. An Expanded Palette of Genetically Encoded Ca ${ }^{2+}$ indicators. Science 2011, 557, 1888-1891. [CrossRef] [PubMed]

90. Evers, T.H.; Appelhof, M.A.M.; de Graaf-Heuvelmans, P.T.H.M.; Meijer, E.W.; Merkx, M. Ratiometric Detection of Zn(II) Using Chelating Fluorescent Protein Chimeras. J. Mol. Biol. 2007, 374, 411-425. [CrossRef] [PubMed]

91. Betolngar, D.B.; Erard, M.; Pasquier, H.; Bousmah, Y.; Diop-Sy, A.; Guiot, E.; Vincent, P.; Mérola, F. pH sensitivity of FRET reporters based on cyan and yellow fluorescent proteins. Anal. Bioanal. Chem. 2015, 407, 4183-4193. [CrossRef] [PubMed]

92. Schö, G. Calcium Signals from the Vacuole. Plants 2013, 2, 589-614. [CrossRef] 
93. Bischof, H.; Rehberg, M.; Stryeck, S.; Artinger, K.; Eroglu, E.; Waldeck-Weiermair, M.; Gottschalk, B.; Rost, R.; Deak, A.T.; Niedrist, T.; et al. Novel genetically encoded fluorescent probes enable real-time detection of potassium in vitro and in vivo. Nat. Commun. 2017, 8, 1422. [CrossRef] [PubMed]

94. Shen, Y.; Wu, S.; Rancic, V.; Qian, Y.; Miyashita, S. Genetically encoded ratiometric indicators for potassium ion. bioRxiv 2018. [CrossRef]

95. Lindenburg, L.H.; Vinkenborg, J.L.; Oortwijn, J.; Aper, S.J.A.; Merkx, M. MagFRET: The First Genetically Encoded Fluorescent $\mathrm{Mg}^{2+}$ Sensor. PLoS ONE 2013, 8, e82009. [CrossRef] [PubMed]

96. Maeshima, K.; Matsuda, T.; Shindo, Y.; Imamura, H.; Tamura, S.; Imai, R.; Kawakami, S.; Nagashima, R.; Soga, T.; Noji, H.; et al. A transient Rise in Free $\mathrm{Mg}^{2+}$ Ions Released from ATP-Mg Hydrolysis Contributes to Mitotic Chromosome Condensation. Curr. Biol. 2018, 28, 444-450. [CrossRef] [PubMed]

97. Hires, S.A.; Zhu, Y.; Tsien, R.Y. Optical measurement of synaptic glutamate spillover and reuptake by linker optimized glutamate-sensitive fluorescent reporters. Proc. Natl. Acad. Sci. USA 2008, 105, 4411-4416. [CrossRef] [PubMed]

98. Marvin, J.S.; Borghuis, B.G.; Tian, L.; Cichon, J.; Harnett, M.T.; Akerboom, J.; Gordus, A.; Renninger, S.L.; Chen, T.W.; Bargmann, C.I.; et al. An optimized fluorescent probe for visualizing glutamate neurotransmission. Nat. Methods 2013, 10, 162-170. [CrossRef] [PubMed]

99. Helassa, N.; Dürst, C.D.; Coates, C.; Kerruth, S.; Arif, U.; Schulze, C.; Wiegert, J.S.; Geeves, M.; Oertner, T.G.; Török, K. Ultrafast glutamate sensors resolve high-frequency release at Schaffer collateral synapses. Proc. Natl. Acad. Sci. USA 2018, 1-6. [CrossRef] [PubMed]

100. Bogner, M.; Ludewig, U. Visualization of arginine influx into plant cells using a specific FRET-sensor. J. Fluoresc. 2007, 17, 350-360. [CrossRef] [PubMed]

101. Yao, Y.; Jones, E.; Inoki, K. Lysosomal regulation of mTORC1 by amino acids in mammalian cells. Biomolecules 2017, 7, 51. [CrossRef] [PubMed]

102. Suzuki, K.; Nagai, T. Recent progress in expanding the chemiluminescent toolbox for bioimaging. Curr. Opin. Biotechnol. 2017, 48, 135-141. [CrossRef] [PubMed]

103. Valiadi, M.; Iglesias-Rodriguez, D. Understanding Bioluminescence in Dinoflagellates-How Far Have We Come? Microorganisms 2013, 1, 3-25. [CrossRef] [PubMed]

(C) 2018 by the authors. Licensee MDPI, Basel, Switzerland. This article is an open access article distributed under the terms and conditions of the Creative Commons Attribution (CC BY) license (http:/ / creativecommons.org/licenses/by/4.0/). 